\title{
Review \\ A Critical Review on the Use of Ionic Liquids in Proton Exchange Membrane Fuel Cells
}

\author{
Adnan Alashkar ${ }^{1}$, Amani Al-Othman $^{2, *} \mathbb{0}$, Muhammad Tawalbeh ${ }^{3,4}\left(\mathbb{D}\right.$ and Muhammad Qasim ${ }^{2}$ \\ 1 Materials Science and Engineering Ph.D. Program, Department of Chemical Engineering, \\ American University of Sharjah, Sharjah P.O. Box 26666, United Arab Emirates; b00028197@alumni.aus.edu \\ 2 Department of Chemical Engineering, American University of Sharjah, \\ Sharjah P.O. Box 26666, United Arab Emirates; mqasim@aus.edu \\ 3 Department of Sustainable and Renewable Energy Engineering, University of Sharjah, \\ Sharjah P.O. Box 27272, United Arab Emirates; mtawalbeh@sharjah.ac.ae \\ 4 Sustainable Energy \& Power Systems Research Centre, Research Institute of Sciences \& Engineering (RISE), \\ University of Sharjah, Sharjah P.O. Box 27272, United Arab Emirates \\ * Correspondence: aalothman@aus.edu
}

check for updates

Citation: Alashkar, A.; Al-Othman, A.; Tawalbeh, M.; Qasim, M. A Critical Review on the Use of Ionic Liquids in Proton Exchange Membrane Fuel Cells. Membranes 2022, 12, 178. https://doi.org/ $10.3390 /$ membranes 12020178 Academic Editor: Patric Jannasch

Received: 17 December 2021 Accepted: 31 January 2022

Published: 2 February 2022

Publisher's Note: MDPI stays neutral with regard to jurisdictional claims in published maps and institutional affiliations.

Copyright: (C) 2022 by the authors. Licensee MDPI, Basel, Switzerland. This article is an open access article distributed under the terms and conditions of the Creative Commons Attribution (CC BY) license (https:// creativecommons.org/licenses/by/ $4.0 /)$.

\begin{abstract}
This work provides a comprehensive review on the incorporation of ionic liquid (ILs) into polymer blends and their utilization as proton exchanges membranes (PEM). Various conventional polymers that incorporate ILs are discussed, such as Nafion, poly (vinylidene fluoride), polybenzimidazole, sulfonated poly (ether ether ketone), and sulfonated polyimide. The methods of synthesis of $\mathrm{IL} /$ polymer composite membranes are summarized and the role of ionic liquids as electrolytes and structure directing agents in PEM fuel cells (PEMFCs) is presented. In addition, the obstacles that are reported to impede the development of commercial polymerized IL membranes are highlighted in this work. The paper concludes that the presence of certain ILs can increase the conductivity of the PEM, and consequently, enhance the performance of PEMFCs. Nevertheless, the leakage of ILs from composite membranes as well as the limited long-term thermal and mechanical stability are considered as the main challenges that limit the employment of IL/polymer composite membranes in PEMFCs, especially for high-temperature applications.
\end{abstract}

Keywords: proton exchange membrane; fuel cells; ionic liquids; polymers; Nafion membrane

\section{Introduction}

Over recent decades, renewable energy systems have been utilized to meet the increasing demand for power and energy. Among these renewable energy systems, fuel cells seem to be receiving extra attention. A fuel cell produces electricity by utilizing hydrogen or other fuels via an electrochemical reaction. Fuel cells are suitable for stationary and portable applications. In addition, they serve as a potential candidate for transportation due to their high power density, low operating temperature, and dynamic characteristics [1]. Fuel cells operate at a higher efficiency compared to combustion engines [2]. Fuel cells have been reported to convert chemical energy to electricity with a theoretical efficiency of about $83 \%$ for hydrogen fuel cells specifically [3]. This efficiency is defined based on the ratio of the amount of Gibbs free energy divided by the enthalpy or the heat of combustion for the overall reaction in a hydrogen fuel cell. As a result, fuel cells offer several advantages when compared to conventional combustion engines. In addition to superior efficiency, fuel cells have less carbon dioxide and greenhouse gas (GHG) emissions compared to combustion engines [4]. In fact, during the operation of hydrogen fuel cells, there are no carbon dioxide or air pollutants emissions. Another advantage of fuel cells is their silent operation, as they possess fewer dynamic parts when compared to combustion engines.

Proton-exchange membrane fuel cells (PEMFCs) have received considerable research interest recently. PEMFCs have an all-solid structure that makes them ideal for transport 
applications, stationary, and portable applications. These fuel cells utilize a special polymer electrolyte membrane for conducting protons. PEMFCs can produce clean energy while operating at temperatures lower than other types of fuel cells. PEMFCs are also distinguished by their silent operation and all-solid membrane structure due to the polymer electrolyte. Lately, research has been conducted to enhance their durability, cost, and overall performance. However, improvements in the technical and economical aspects of the fuel cell are still required for commercialization. Research has been focusing on the optimization of the fuel cell by optimizing the configuration, materials, conformation, and structure of the catalyst layer [5-9]. For instance, several research studies have focused on decreasing the cost of PEMFCs by enhancing the electrolyte conductivity [10-13]. Simultaneously, in order to enhance the safety of the fuel cells, nonflammable and nonvolatile electrolytes have been investigated.

PEMFCs have been investigated for their application in electric vehicles. Although the industry is predominantly reliant on lithium-ion batteries, PEMFCs have great potential in powering and improving the performance of electric vehicles [14]. Moreover, PEMFCs are able to tap into the market and compete with lithium-ion batteries to offer electric vehicles that have a long driving range, high utilization, and low cost $[14,15]$. The main advantage of PEMFCs over batteries, especially in the long-range market, is the high specific energy and energy density of hydrogen [16]. In addition, for future high-utilization transportation, hydrogen is a natural fit when looking at grid compatibility and fast refueling.

Ionic liquids (ILs) possess desired characteristics such as excellent ionic conductivity even at anhydrous conditions [17]. Many research efforts have been conducted on the incorporation of ILs into PEMFCs, yet, review articles pertaining to the subject are either outdated or focused only on certain types of polymers or ILs [18,19]. This work provides a comprehensive review on the recent use of ILs in PEMFCs, focusing mainly on systems employing IL/polymer composite membranes while outlining the future research needs and challenges. This review has also presented the opportunities for the use of ILs in high-temperature operations and focused on presenting all types of polymers evaluated in the literature for this purpose.

\section{Proton Exchange Membrane Fuel Cells (PEMFCs)}

A PEMFC consists of electrodes, an electrolyte, a catalyst, and diffusion layers. Figure 1 depicts a diagram of a PEMFC [18]. The membrane and the catalyst layers create the membrane electrode assembly. The PEM serves a vital role, as it is responsible for separating the gaseous reactants, conducting protons, and electrically insulating the electrons. Membranes ideal for PEMFCs should be of low cost and possess desirable properties such as high proton conductivity, high mechanical strength, high thermal, chemical, and electrochemical stability, and low oxygen and fuel crossover. In that regard, perfluorosulfonic acid (PFSA) membrane, i.e., Nafion of Dupont, is most commonly in PEMFCs, due to its superb chemical stability, outstanding strength, and high ionic conductivity [20,21]. Nevertheless, the conductivity of the membrane decreases significantly when the temperature exceeds $100{ }^{\circ} \mathrm{C}$, rendering it undesirable for high-temperature processes.

Proton exchange membranes could be classified based on their properties and functions. The structure of the PFSA membranes consists of a fluorinated backbone with a fluorocarbon side chain, in addition to sulphonic acid ion clusters attached to the side chains of the backbone. These membranes are prone to dehydration at temperatures above $80^{\circ} \mathrm{C}$, which, consequently, reduces their proton conductivity. In order to overcome the challenges faced by PFSA membranes, researchers have adopted partially fluorinated membranes [22]. The structure of the partially fluorinated membranes consists of a fluorocarbon base with a hydrocarbon side chain grafted on the backbone. Hence, the structure allows for the use of inexpensive base films with a low crossover, in addition to forming a relatively stronger compound compared to PFSA membranes. Moreover, the cost of the membrane is reduced since a less fluorinated polymer is needed; nevertheless, the reduction in the 
cost comprises the proton conductivity resulting in low performance and less durable membrane compared to a perfluorinated polymer.

\section{Electrical Current (DC) $\rightarrow$}

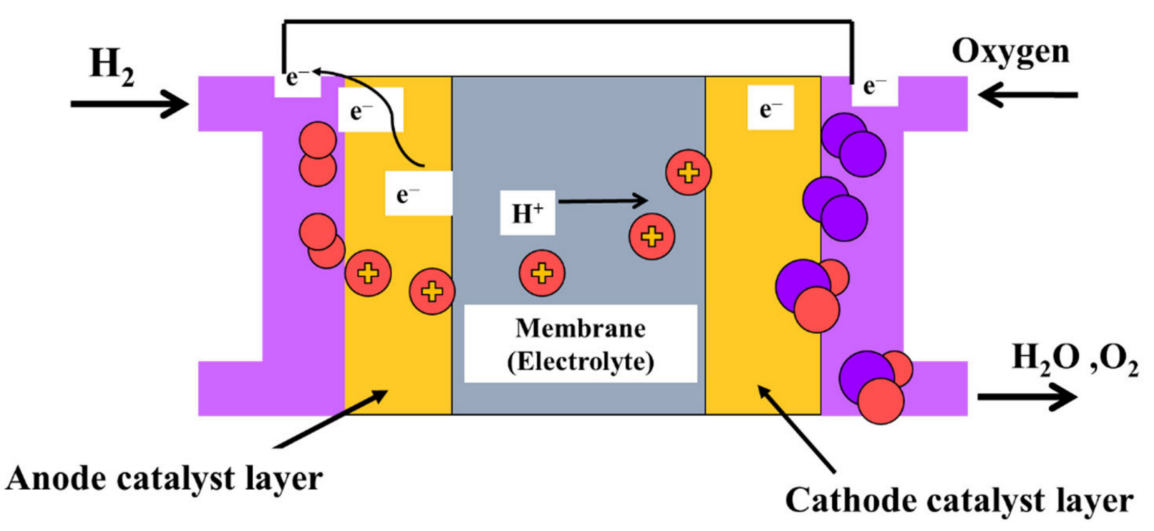

Figure 1. Schematic diagram of a PEMFC.

Researchers have studied the use of nonfluorinated membranes as alternatives to conventional PFSA membranes in PEMFCs. The nonfluorinated membranes consist of a hydrocarbon base, normally altered by the addition of polar or sulphonic groups. The polymer membranes should have a proton conductor component. Research in this context focused first on poly (arylene ether) materials, due to their high stability, availability, and processibility [23]. Nevertheless, due to the short lifetime and excessive swelling of poly (arylene ether) membranes, efforts were directed towards optimizing other nonfluorinated materials and acid-base membranes. The latter involves the incorporation of acid components (such as sulfonated compounds) into an alkaline polymer base such as polybenzimidazole (PBI). The mixture of the acid-base membrane allows for high thermal and chemical stabilities, in addition to a proton conductivity in the same range as, or even higher than, that of Nafion. Among the strong acids, phosphoric acid $\left(\mathrm{H}_{3} \mathrm{PO}_{4}\right)$ and sulphuric acid $\left(\mathrm{H}_{2} \mathrm{SO}_{4}\right)$ show valuable proton conductivities in both wet and anhydrous forms [24,25]. PBI is known for its high chemical and thermal stability. However, the main disadvantage of the acid-base membrane is the leaching of acid during operation, which limits the durability of the membrane [18]. Table 1 provides a summary of the classification of membranes in terms of their category and structure. A detailed summary of the structure, physical properties, and performance of membranes can be found in [26].

Table 1. Summary of membranes classification.

\begin{tabular}{cc}
\hline Category & Structure \\
\hline Perfluorinated Membranes & Fluorinated backbone with fluorocarbon side chain. Ex. Nafion \\
\hline Partially Fluorinated Membrane & Fluorocarbon or Hydrocarbon base. Ex. PVDF \\
\hline Nonfluorinated Membrane & Hydrocarbon or aromatic base. Ex. PBI \\
\hline Acid-base Membranes & Integration of acid in an alkaline polymer base. Ex. $\mathrm{H}_{3} \mathrm{PO}{ }_{4}$ \\
\hline Ionic Liquid Membranes & Formed between an organic cation and an organic/inorganic anion \\
\hline
\end{tabular}

Significant research has been performed on developing novel proton exchange membranes for use in fuel cells $[12,13,27]$. These efforts have achieved moderate success. However, it is clear that these membranes still need improvement to become commercially viable. Researchers have investigated the modification of Nafion membranes by incorporating bifunctional compounds, such as silica, zeolites, and carbon nanotubes, to enhance water retention and increase proton conductivity at higher temperatures [28].

The electrodes of the proton exchange membrane represent another vital component in PEMFCs arrangement. In order to overcome the challenges halting the utilization of 
PEMFCs as an efficient and competitive energy source, the performance and durability of the electrolyte and electrodes need to be improved. Typically, the electrodes consist of three layers: backing, gas diffusion, and catalyst layers [29]. The catalyst layer usually consists of noble metals, such as platinum, as a catalyst; however, platinum is quite expensive and accounts for $55 \%$ of the PEMFC cost. In order to lower the cost without significantly compromising the performance of PEMFCs, platinum alloys (such as $\mathrm{Pt}-\mathrm{Ru}, \mathrm{Pt}-\mathrm{Co}, \mathrm{Pt}-\mathrm{Pd}$, etc.) are employed as catalysts [29]. Another method is the use of platinum bimetal, which involves adding metals such as $\mathrm{Fe}, \mathrm{Cu}, \mathrm{Co}$, and $\mathrm{Ni}$ to the platinum catalyst. Moreover, the catalyst ink distribution and the agglomeration of catalyst particles are crucial to the performance of the catalyst layer.

In the subsequent sections, the focus will be on discussing the recent developments in the incorporation of ILs in PEMFCs polymer membranes.

\section{Ionic Liquids Applications in PEM}

ILs are salts in the liquid state, typically defined as liquid electrolytes composed entirely of ions without the use of solvents. Some ILs flow freely as liquids at room temperature. These ILs are referred to as room-temperature ILs (RTILs). Furthermore, ILs possess a number of desirable properties for electrochemical applications, such as: very low volatility, nonflammable characteristics, high thermal and electrochemical stability, and high ionic conductivity under anhydrous conditions [19]. Given the excellent properties of ILs, and the fact that they are made up entirely from ions and do not contain solvents, ILs can be combined and/or modified to tailor their properties that are desirable for specific applications. For instance, extensive research has been carried for the employment of IL as electrolytes in solar cells, batteries, and fuel cells [30-32].

The critical aspect of the fuel-cell performance is stability, which is heavily impacted by the conductivity of the IL. Typically, ILs possess conductivities that are in the range $1.0 \times 10^{-4}-1.8 \times 10^{-4} \mathrm{~S} / \mathrm{cm}$ [19]. For instance, ILs based on imidazolium cations exhibit conductivity of approximately $1 \mathrm{mS} / \mathrm{cm}$ [19]. Other ILs, such as those based on pyrrolidinium, piperidinium, pyridinium, and tetraalkylammonium cations, show lower conductivities (in the range $1.0 \times 10^{-4}-5 \times 10^{-3} \mathrm{~S} / \mathrm{cm}$ ). The counter ion influences the reduction potential of the cation or the anion. It has been reported that the presence of halide anions, such as $\mathrm{F}^{-}$and $\mathrm{Br}^{-}$, limits the stability to 2-3 V. However, in the case of the bis(trifluoromethylsulphonyl)imide $\left(\mathrm{TFSI}^{-}\right.$) anion, higher stability in the region of $4.5 \mathrm{~V}$ could be obtained due to the oxidization of the anion at a high anodic potential [33]. ILs with tetraalkylammonium cations display improved stability in the range of 4.0-5.7 V due to the cathodic reduction occurring at temperately negative potentials [34].

ILs can be either protic or aprotic. Protic ILs are suitable for application in fuel cells due to the reactivity of the active proton available at the cation. On the other hand, aprotic ILs, i.e., not protic, possess low melting points owing to the padding of large irregular cations with small anions. Hence, aprotic ILs are good candidates for lithium batteries applications due to their high mobility and ion concentration.

Protic ILs result from combining a Brønsted acid and a base. The hydrogen-bonded network is formed by the availability of proton acceptor and donor sites caused by the migration of the protons from the acid to the base. Protic ILs could be formed with protons existing on the cation, such as triethylammonium bromide, 1-methylimidazolium chloride, and pyridinium bromide [19]. Another method for forming protic ILs is by attaching acidic functional groups such as sulfonate or sulfone-amide to the cation as the basis of protons in the architecture. Another type of protic ILs called multiprotic ILs are characterized by the presence of a functional group and a proton on the anion or the cation. These ILs are referred to as multiprotic since multiple protons exist in their structure.

\subsection{Preparation of Polymerized Ionic Liquid Membranes}

Polymerization of ILs containing a polymeric group appears to be the most commonly used technique for creating polymeric electrolytes. Polymerised ILs (PILs) comprise a wide 
variety of structures depending on the nature of the final application. Figure 2 shows a summary of poly(ILs).
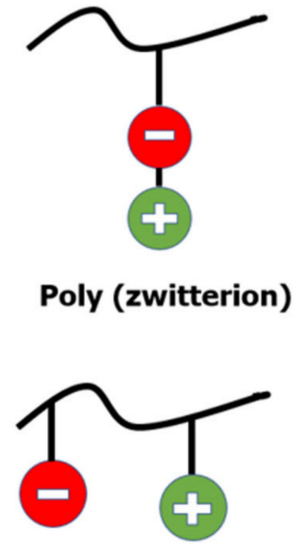

Copolymer

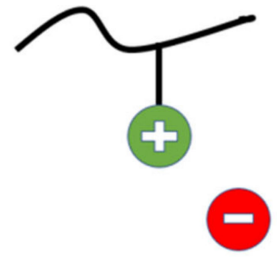

Poly (cation)

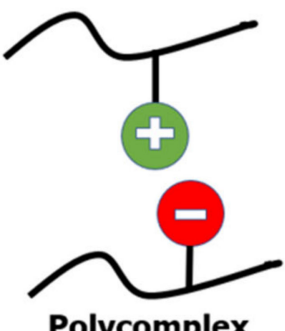

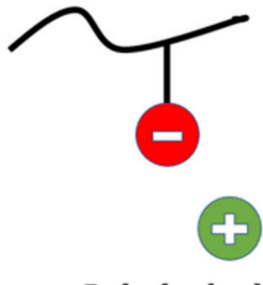

Poly (anion)

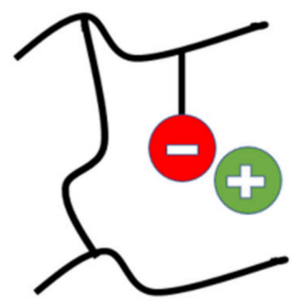

Network

Figure 2. Depiction of poly (ILs).

Mainly, PILs can be synthesized by direct polymerization of IL monomers or by chemical modification of existing polymers. Direct polymerization can be achieved by techniques such as free or controlled radical polymerization, reversible addition-fragmentation chain transfer polymerization (RAFT), and atom transfer radical polymerization (ATRP). The IL monomers that are usually employed in this method include methacryloyl, styrenic, and 1-vinylimidazolium groups. Controlled radical polymerization offers the advantage of designing and controlling the macromolecular construction of the IL species [18]. The ATRP and RAFT, on the other hand, are mainly utilized for the preparation of homopolymers and block copolymers of IL. Besides these, photopolymerization can be used, which is an intuitive method for the formation of PILs composites based on imidazolium-based monomer for application of gas separation membranes [35]. The PILs synthesized using the chemical alteration of existing polymers will adopt the structure of the original polymer in addition to a certain degree of polymerization.

The ionic conductivity of the IL monomer decreases as the glass temperature increases and the mobility and number of mobile ions decreases. The decrease in ionic conductivity is the most common disadvantage of PILs. This limitation can be addressed by increasing the concentration of carrier ions or modifying the polymer structure to increase the mobility of ions. For example, Põhako-Esko et al. [36] investigated the addition of 1-ethyl-3-methylimidazolium tetrafluoroborate [EMIM] $\left[\mathrm{BF}_{4}\right]$ to methacrylate-type PILs. It was reported that an increase in the amount of $[\mathrm{EMIM}]\left[\mathrm{BF}_{4}\right]$ resulted in an increased ionic conductivity $(0.1 \mathrm{mS} / \mathrm{cm}$ compared to only $0.01 \mathrm{mS} / \mathrm{cm}$ for the unmodified PIL).

The addition of the ILs manipulates the morphology of the membranes, where ILs are known to be structure-directing agents. For instance, GSaiz et al. [37] studied the effect of ILs on the morphology of a PVDF-HFP membrane. The Scanning Electron Microscopy (SEM) results showed the presence of several morphologies and different hydrophobic properties depending on the selected IL. Figure 3 shows the cross-sectional SEM view of PVDF-HFP-based membranes with the presence of ILs. It can be seen that the pristine PVDFHFP membranes show a high degree of porosity; however, membranes with ILs possess a different structure. For instance, PVDF-HFP/[dema][TfO] composites show no pores when prepared at room temperature, or heated at $100{ }^{\circ} \mathrm{C}$. Nevertheless, a spherulites structure is observed when the solvent evaporates at $80^{\circ} \mathrm{C}$. Meanwhile, PVDF-HFP/[MIm] $\left[\mathrm{NTf}_{2}\right]$ composites showed no porosity. This indicates that hydrophilic ILs induce porosity when 
compared to hydrophobic ones. In general, the addition of ILs improves the morphology of the membranes as they reduce the occurrence and extent of variations on the membrane that causes local heat spots and leads to holes in membranes [38,39].

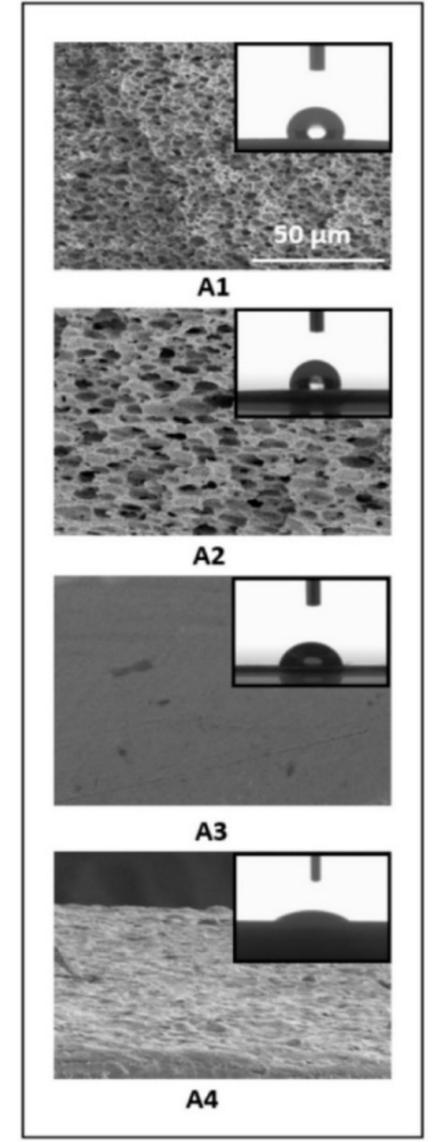

(A)

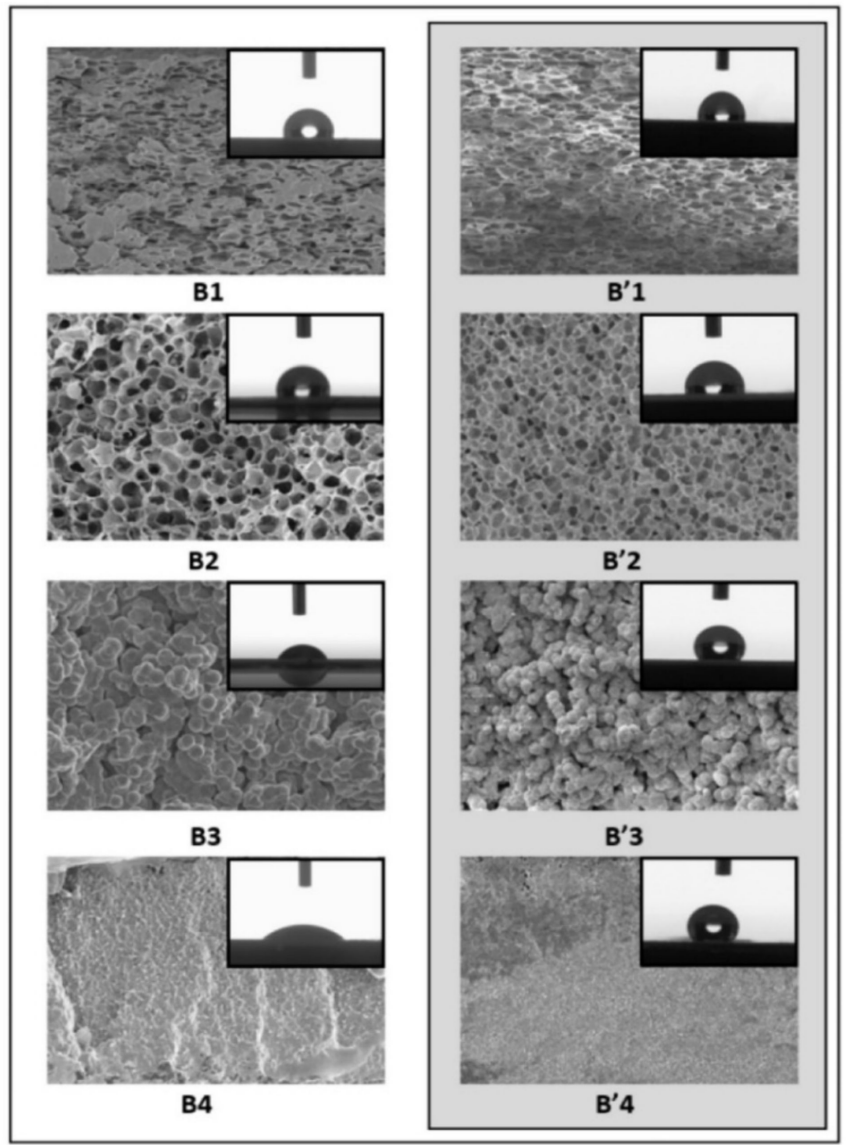

(B)

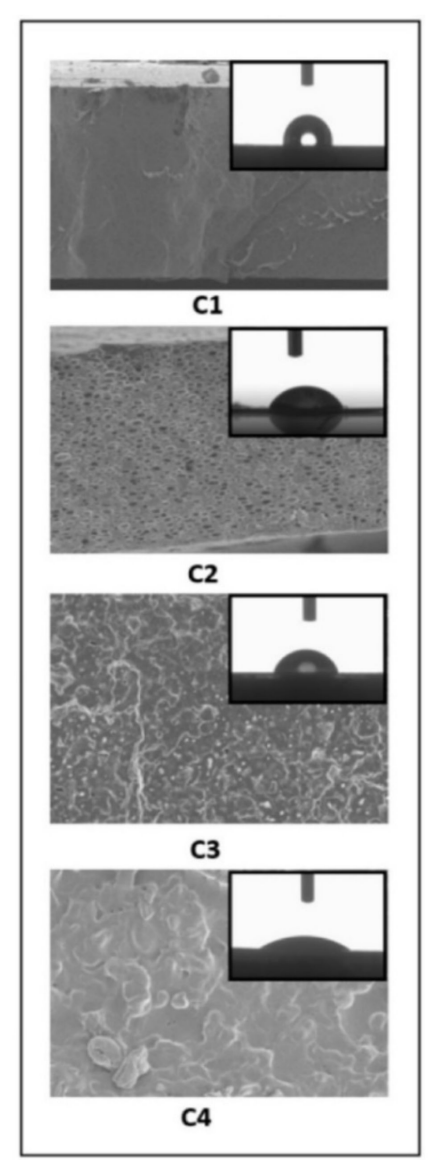

(C)

Figure 3. Cross-sectional SEM images for of PVDF-HFP membranes (1), PVDF-HFP/[MIm] [Cl] (2), $\mathrm{PVDF}-\mathrm{HFP} /[$ dema][TfO] (3) and PVDF-HFP/[MIm][NTf 2 ] (4), prepared at room temperature (A), $80{ }^{\circ} \mathrm{C}(\mathrm{B})$ and $100{ }^{\circ} \mathrm{C}(\mathrm{C}) . \mathrm{B}^{\prime}$ represents the membranes prepared at $80{ }^{\circ} \mathrm{C}$ after immersion in water for $48 \mathrm{~h}$ [37], Reproduced with permission from Paula GSaiz, et al., Materials \& Design; published by Elsevier, 2018.

\subsection{Ionic Liquids as Electrolytes in PEMFCs}

Protic ILs represent promising candidates in PEM membranes due to several advantages including thermal stability, low volatility, and high conductivity above $100{ }^{\circ} \mathrm{C}$. As established, Protic ILs are in base-acid equilibrium since they are created by the neutralization reaction between an acid and a base. Hence, the protic IL's structure consists of a neutral species, a cation, and an anion. The neutral species are formed by the transport process of the back proton, where in case of incomplete proton transport, the ILs' boiling could occur prior to the decomposition resulting in a decrease in the thermal stability, especially at high temperatures.

The proton transfer occurs via Grotthuss and vehicle mechanisms [19]. In the former mechanism, the proton moves from one water molecule to another utilizing the availability of hydrogen bonds. In the vehicle mechanism, the protons move by migration. In some cases, both mechanisms can coincide in one system. For protic ILs, the proton transport is generally conducted by the vehicle mechanism, as there are no sites in the structure to receive the protons, therefore the cations carrying active protons travel to transport those protons. In protic ILs containing hydrogen phosphite and hydrogen sulphate anion, 
the anions can serve as a proton donor or acceptor, hence allowing the coexistence of the Grotthuss and vehicle mechanisms. Nonetheless, the viscosity affects the ionic conductivity of the protic ILs [40].

The employed IL greatly affects the performance of PEMFC. The effect of the IL on the PEM can be easily studied by observing the values of the open circuit potential (OCP). The OCP mainly depends on the solubility and mass transfer coefficient of the reactants oxygen $\left(\mathrm{O}_{2}\right)$ and hydrogen $\left(\mathrm{H}_{2}\right)$, where a higher OCP means better performance. Miran et al. [41] were among the researchers who studied hydrogen fuel cells and acid dissociation constant ( $\mathrm{pKa}$ ) and its influence on proton transfer from acids to bases in protic ILs. They concluded that the OCP increased with increasing equilibrium constant up to 17, after which it decreased. This led to the conclusion that the proton migration is hindered by the value of $\mathrm{pKa}$ and the strong $\mathrm{N}-\mathrm{H}$ bond.

Numerous research has been conducted to study the feasibility of employing protic ILs as proton conductors for PEMFC. Table 2 shows the conductivity values of common protic ILs used in fuel-cell applications. Nakamoto et al. [42] prepared protic ILs and melts by combining Benzimidazolium (bzlm) and bis(trifluoromethanesulphonyl)imide (TFSI) at different molar ratios. The resulting protic IL showed thermal stability at $350{ }^{\circ} \mathrm{C}$ and remained stable under oxygen reduction and hydrogen oxidation reactions. The measured conductivity at $140{ }^{\circ} \mathrm{C}$ was $8.3 \mathrm{mS} / \mathrm{cm}$. Moreover, it was shown that [Bzlm][TFSI] melts can be utilized as an electrolyte at $150{ }^{\circ} \mathrm{C}$ for dry conditions. Nevertheless, at identical operating parameters, $\mathrm{H}_{3} \mathrm{PO}_{4}$ electrolyte exhibited larger open-circuit potentials than [Bzlm][TFSI]. Noda et al. [43] prepared protic IL using imidazole (Im) and TFSI at various molar ratios. The resulting protic IL showed thermal stability at $300{ }^{\circ} \mathrm{C}$ and above while increasing the oxygen reduction and hydrogen oxidization reactions. Nonetheless, the adsorption of imidazolium on the electrode caused the electric current to decline. Wippermann et al. [44] produced an IL of (2-sulfoethylammonium trifluoromethanesulfonate) [2-sea][TfO] (95 $\mathrm{wt} \%$ ) dissolved in water that displayed a conductivity 20 times less than $\mathrm{H}_{3} \mathrm{PO}_{4}$ at a temperature of $130^{\circ} \mathrm{C}$. However, at a lower temperature of $90^{\circ} \mathrm{C}$, the solution showed a higher activity for oxygen reduction reaction when compared to $\mathrm{H}_{3} \mathrm{PO}_{4}$. Moreover, protic IL [2-FPy]TF improved the fuel performance by displaying an increase of 15\% in the polarization curve represented for a $0.1 \mathrm{~V}$ cell potential increase at $80{ }^{\circ} \mathrm{C}$ [45].

Table 2. Conductivity of common protic IL in fuel cells.

\begin{tabular}{cccc}
\hline Protic IL & Conductivity $(\mathbf{m S} / \mathbf{c m})$ & Temperature $\left({ }^{\circ} \mathbf{C}\right)$ & Ref. \\
\hline [dema][TfO] & 43 & 120 & {$[46]$} \\
{$[$ dema]HSO } & 30 & 30 & {$[47]$} \\
{$[$ dema][TFSA] } & 1.1 & 30 & {$[48]$} \\
{$[\mathrm{MTBDH}] \mathrm{TFSI}$} & 7.4 & 30 & {$[42]$} \\
{$[\mathrm{bzlm}][\mathrm{TFSI}]$} & 1.54 & 140 & {$[49]$} \\
$(\mathrm{Btmps}) / \mathrm{HN}(\mathrm{Tf})_{2}$ & 8.3 & 100 & {$[50]$} \\
{$\left[\mathrm{C}_{2} \mathrm{H}_{3} \mathrm{~N}_{3}\right] /\left[\mathrm{CH}_{3} \mathrm{SO}_{3} \mathrm{H}\right]$} & 1 & 200 & {$[51]$} \\
{$[\mathrm{MIm}][\mathrm{TFSI}]$} & 149 & 25 & {$[52]$} \\
{$[\mathrm{MPz}][\mathrm{TFSI}]$} & 7.23 & 90 & {$[53]$} \\
ITSA & 12 & 150 & {$[54]$} \\
TFAPA & 32.6 & 180 & {$[55]$} \\
TEA-TF & 30 & 130 & {$[56]$} \\
TOA-TF & 31 & 25 &
\end{tabular}


Table 2. Cont.

\begin{tabular}{|c|c|c|c|}
\hline Protic IL & Conductivity (mS/cm) & Temperature $\left({ }^{\circ} \mathrm{C}\right)$ & Ref. \\
\hline$[\mathrm{DMEIm}] \mathrm{H}_{2} \mathrm{PO}_{4}$ & 70 & 120 & [57] \\
\hline $\mathrm{BG}-\mathrm{BF}_{4}$ & 180 & 180 & [58] \\
\hline$[\mathrm{EMIm}] \mathrm{HSO}_{4}$ & 16 & 85 & [59] \\
\hline [morph][HCOO] & 9.92 & 60 & [60] \\
\hline [Mmorph][HCOO] & 16.77 & 60 & [60] \\
\hline [Emorph][HCOO] & 12.17 & 60 & [60] \\
\hline [pyrr] $\left[\mathrm{NO}_{3}\right]$ & 50.1 & 25 & [61] \\
\hline [pyrr] $\mathrm{HSO}_{4}$ & 5.8 & 25 & [61] \\
\hline [pyrr][HCOO] & 32.9 & 25 & [61] \\
\hline [pyrr] $\left[\mathrm{CH}_{3} \mathrm{COO}\right]$ & 5.9 & 25 & [61] \\
\hline$[$ pyrr $]\left[\mathrm{CF}_{3} \mathrm{COO}\right]$ & 16.4 & 25 & [61] \\
\hline [pyrr] $\left[\mathrm{C}_{7} \mathrm{H}_{15} \mathrm{COO}\right]$ & 0.8 & 25 & [61] \\
\hline [pyrr][TFSA] & 39.6 & 130 & [62] \\
\hline [EMIM][TFSI] & 5.4 & 150 & [63] \\
\hline$[\mathrm{BMIm}]\left[\mathrm{BF}_{4}\right]$ & 1.2 & 25 & [64] \\
\hline
\end{tabular}

Some attempts have been made to improve the physical and chemical properties of protic ILs. This includes the incorporation of organic and inorganic compounds. For instance, [EMIM] $\mathrm{HSO}_{4}$ was tested as an electrolyte in a PEMFC [59]. The results showed that [EMIM] $\mathrm{HSO}_{4}$ is a promising electrolyte especially at elevated temperatures above $145^{\circ} \mathrm{C}$. [EMIM][TFSI] has also been tested as an electrolyte for PEMFC, and it showed good thermal stability for temperatures of $350^{\circ} \mathrm{C}$ and above with a conductivity of $5.4 \mathrm{mS} / \mathrm{cm}$ [63]

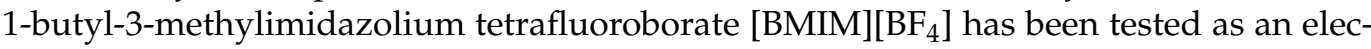
trolyte for fuel-cell applications and displayed a conductivity of $1.2 \mathrm{mS} / \mathrm{cm}$ [64]. Li et al. [65] established hybrid PEMs based on [dema][TfO] and $\mathrm{SiO}_{2}$ monoliths. The membranes showed extremely high conductivity of $10 \mathrm{mS} / \mathrm{cm}$; however, the membrane brittleness required improvement. Moreover, clay multistructures were studied due to their low cost, ease of availability, and high sorption capacity. Takashi et al. [66] intercalated three different ILs into montmorillonite clay, namely 1-ethyl-3-methylimidazolium octylsulfate [EMIM] $\left[\mathrm{OCSO}_{4}\right], \mathrm{N}, \mathrm{N}, \mathrm{N}$-trimethyl-N-propylammonium bis (trifluoromethanesulfonyl) imide [TMPA][TFSI], and N,N-diethyl-N-methyl-N-(2-methoxyethyl) ammonium bis (trifluoromethanesulfonyl)imide [DEMET][TFSI]. The ionic conductivities achieved for [DEMET][TFSI] and [TMPA][TFSI] were 1.88 and $1.99 \mathrm{mS} / \mathrm{cm}$, respectively. Protic ILs based on morpholinium (N-ethylmorpholinium, N-methylmorpholinium, and morpholinium cations) were synthesized by Yoshizawa-Fujita et al. [49]. In their work, the protic ILs showed proton conductivities around $10-16.8,21-29$, and $1 \mathrm{mS} / \mathrm{cm}$ at 25,100 , and $150{ }^{\circ} \mathrm{C}$, respectively.

The previous literature shows that ILs are promising alternatives to conventional electrolytes as proton conductors for PEMs. The main attractive feature of utilizing ILs as electrolytes is the high conductivities they possess at high temperatures, even in anhydrous conditions. The ILs are synthesized as film-like membranes by supporting them on polymers for PEMFC applications. In the following sections, the various polymers used in PEMFCs are discussed.

\subsection{Polymer-Ionic Liquids Membranes}

Solid-state electrolytes are the desirable method for preparing ILs electrolytes since the film structure is required by electronic devices. In order to achieve the film-like membrane, IL can be mixed with ordinary polymers. This results in a change in the glass transition temperature and enhances the properties of hydrogen transport. Nevertheless, this technique comprises the properties of the IL and the strength of the membrane [67]. An example of the technique is the polymerization of methylmethacrylatein1-ethyl-3-methylimidazolium bis(trifluoromethanesulfonyl)imide ([ $\left.\left.\mathrm{C}_{2} \mathrm{mim}\right][\mathrm{TFSI}]\right)$ in the presence of a cross-linking agent to synthesize a self-standing polymer gel with a proton conductivity of $10 \mathrm{mS} / \mathrm{cm}$ at room 
temperature [68]. In the following sections, we provide a review of all types of membranes that have been investigated with ILs. It should be noted here that these membranes can be classified into sulfonated fluorine-based (e.g., Nafion) and hydrocarbon-based membranes. Hydrocarbon-based membranes are generally categorized into aliphatic-based (such as polyimide) or aromatic-based, such as PBI. They are generally characterized by low proton conduction properties as opposed to the PFSA membranes. In addition, there is a difficulty encountered in forming a distinct phase between the hydrophilic and hydrophobic regions, which is another drawback that has limited their application in PEM fuel-cell membranes. Therefore, the most widely used hydrocarbon-based polymer materials that also involve ionic liquids include Nafion, PBI, PI, PVDF, PMMA, and PSS.

\subsubsection{Nafion-Based PEM}

The conductivity of Nafion membranes mainly depends on their water content. A dramatic decrease in Nafion's conductivity is observed for temperatures higher than the boiling point of water. Since high temperature is preferred in PEMFCs due to several advantages, including enhanced kinetics and better water management, Nafion membranes have been modified with a variety of materials including ILs. Diaz et al. [69] studied the behaviour of Nafion 112 membranes modified with 1-butyl-3-(4-sulphobutyl)-imidazoliumtrifluoromethanesulphonate ([HSO 3 -BBIm] [TfO]) and 1-methyl-3-(4-sulphobutyl)-imidazolium bis(trifluoromethylsulphonyl)imide([ $\left.\left.\mathrm{HSO}_{3}-\mathrm{BMIm}\right][\mathrm{TFSI}]\right)$ ILs. The presence of the electrochemically stable imidazolium cation and the highly conductive anions allowed for the enhanced performance of these membranes. The existence of $\left(\left[\mathrm{HSO}_{3}-\mathrm{BBIm}\right][\mathrm{TfO}]\right) \mathrm{im}-$ proved the current density of the fuel-cell membrane to $217 \mathrm{~mA} / \mathrm{cm}$ with the humidification of the inlet gasses. Yuso et al. [70] explored the properties of Nafion 112 membranes combined with n-dodecyltrimethylammonium $\left(\mathrm{DTA}^{+}\right)$. The optimum volume fraction occurred at $68 \% \mathrm{DTA}^{+}$after $22 \mathrm{~h}$ of contact and resulted in higher thermal stability when the membranes are compared at $120^{\circ} \mathrm{C}$. Noto et al. [71] studied Nafion 117 membranes modified with triethylammonium methanesulphonate (TMS) and triethylammonium perfluorobutanesulphonate (TPFBu). The addition of the IL increased the uptake of the membranes (20 and 39 wt.\% for TMS and TPFBu, respectively). The synthesized membrane showed thermal stability up to $140{ }^{\circ} \mathrm{C}$. Sun et al. [72] evaluated the conductivity of anhydrous Nafion membranes impregnated with imidazole-based molten salts in addition to three ILs, namely: 1,2-dimethyl imidazolium trifluoroacetate, imidazolium tri-fluoroacetate, and 1, 2-di-methyl imidazolium trifluoromethane sulfonate. The conductivity was high, at around 3-4 mS/cm. Sood et al. [73] modified Nafion membranes with triethylammmonium trifluorosulfonate. It was found that an increase in the triethylammmonium trifluorosulfonate (TEA-TF) content led to enhanced membrane conductivity and water uptake properties.

The most important factor to consider while manufacturing polymerized IL electrolytes is the compatibly between the IL and the polymer, as it greatly affects the uptake degree of the IL by the polymer. For instance, Schauer et al. [74] examined the compatibility of protic IL, 1-ethylimidazolium trifluoromethanesulfonate [EIM][TfO] and aprotic IL, 1-butyl-3-methylimidazolium trifluoromethanesulfonate [BMIM][TfO] with Nafion, and other polymers including Udel-type polysulfone, polybenzimidazole derivative containing benzofuranone moieties (PBI-O-Ph), and poly(vinylidene fluoride-co-hexafluoropropene) (fluoroelastomer). The results showed that owing to the low solubility of the two IL, they were completely incompatible with the polysulfone polymer. Thus, the conductivity was negligible, as the ionic conductivity structure did not form due to the low solubility. However, in the case of PBI-O-Ph, the IL was partially compatible. Hence, low conductivities were recorded for temperatures above $90{ }^{\circ} \mathrm{C}$. In the case of charged polymers such as Nafion, a marginally higher conductivity was recorded. Lojoiu et al. [75] evaluated the effect of different ILs on Nafion conductivity and found a direct proportional relationship between conductivity and IL uptake. Hence, to maximize the conductivity of the membrane, optimization of the uptake of the IL by the polymer is an important consideration. For instance, $\left[\mathrm{HSO}_{3}-\mathrm{BBIM}\right][\mathrm{TfO}]$ showed an uptake degree of $9.4 \%$ by Nafion, which is 
higher when compared to $1.6 \%$ for $\left[\mathrm{HSO}_{3}-\mathrm{BBIM}\right][\mathrm{TFSI}]$. Consequently, the performance of the resulting membranes was enhanced and a current density of $0.217 \mathrm{~A} / \mathrm{cm}$ was observed [69]. Zanchet et al. [76] fabricated Nafion composite membranes and varied the ILs content, namely 3-triethylammonium propane sulfonic acid tetrafluoroborate (TEA$\mathrm{PSBF}_{4}$ ), 3-triethylammonium propane sulfonic acid hydrogen sulphate (TEA-PSHSO 4 ), and 3-triethylammonium propane sulfonic acid trifluoromethanesulfonate (TEA-PSCF $3 \mathrm{SO}_{3}$ ). The ILs were reported to improve the proton conductivity and stability of the resulting membrane. The results showed that the conductivity increased from $0.093 \mathrm{~S} / \mathrm{cm}$ (for unmodified Nafion) to $0.159 \mathrm{~S} / \mathrm{cm}$ for $5 \mathrm{wt} \%$ (TEA-PSHSO 4 ) $/ \mathrm{Nafion}^{\circ} 8{ }^{\circ} \mathrm{C}$.

The proton transfer mechanism between the anion and the cation in polymerized IL membranes was also investigated in the literature. Kumar and Venkatnathan [77] investigated the proton transfer in polymerized IL membranes in an attempt to aid the selection process of a suitable IL that will boost the conductivity of the polymer. It was reported that the modification enhanced the proton conduction paths. The conductivity of the Nafion/IL membranes was also affected by the dispersion of the IL within the membrane matrix. Under anhydrous conditions and at a temperature of $130{ }^{\circ} \mathrm{C}$, the conductivity was $6 \mathrm{mS} / \mathrm{cm}$ [78].

The addition of silica $\left(\mathrm{SiO}_{2}\right)$ showed an improvement in membranes along with ILs. For example, for Nafion/ $\left(\mathrm{SiO}_{2}\right)_{3.67}(\mathrm{TEA}) /(\mathrm{TEA}-\mathrm{TF})_{1.2}$, a conductivity of $4.7 \mathrm{mS} / \mathrm{cm}$ was reported at $105{ }^{\circ} \mathrm{C}$ [79]. Another example is the Nafion/1-(3-hydroxypropyl)-3methylimidazolium tetrafluoroborid $\left[\mathrm{C}_{3} \mathrm{OHMIM}_{\mathrm{B}} \mathrm{BF}_{4} / \mathrm{SiO}_{2}(50 / 10 \mathrm{wt} \%)\right.$ membrane, which was found to be stable up to a temperature of $405{ }^{\circ} \mathrm{C}$ due to the formation of hydrogen bonds. Moreover, the membrane achieved a conductivity of $55 \mathrm{mS} / \mathrm{cm}$ above $160{ }^{\circ} \mathrm{C}$ and a $100 \%$ increase in the tensile strength compared to pristine Nafion [80]. In another study, the protic IL1-(3-trimethoxysilylpropyl)-2-methylimidazolium tetrafluoroborate [TMSPMIM]BF 4 was employed to functionalize mesoporous $\mathrm{SiO}_{2}$ in order to prevent IL retention. The resulting Nafion membrane showed a 7 -fold increase in conductivity when $3 \mathrm{wt} \%$ functionalized $\mathrm{SiO}_{2}$ were utilized, where a conductivity of $375 \mathrm{mS} / \mathrm{cm}$ was obtained [81]. The use of graphene oxide (GO) to enhance the conductivity of Nafion-based membranes, especially at higher temperatures, has been investigated. Maiti et al. [82] synthesized a membrane using GO, [DMBIM] $\mathrm{H}_{2} \mathrm{PO}_{4}$, and Nafion 117 . At $110{ }^{\circ} \mathrm{C}$, the conductivity was $6.1 \mathrm{mS} / \mathrm{cm}$. Figure 4 shows the influence of temperature on the proton conductivity of the membranes, as well as the effect of the current density on the voltage and power density of the PEMFC operating with hydrogen at $110^{\circ} \mathrm{C}$. The figure shows an enhancement in conductivity and fuel-cell performance (as seen by the polarization curve) upon the modification of Nafion using ILs or additives (e.g., GO).

The structure and length of the side chain of fluorine-based membranes significantly affect the conductivity of the polymer membrane. Fluorine-based polymer electrolyte membranes can also include other types such as Aciplex and Flermon membranes, but to the best of our knowledge, they have not yet been used in PEM fuel-cell membranes with ILs in particular. When it comes to the side chain, and upon the examination of fluorine-based membranes, it can be clearly seen that Nafion is characterized by a long side chain. Aquivion (Solvay) and PFSA (3M) ionomers, on the other hand, have short side chains. The short side chains appear to exhibit more durability, however, they can also affect the crystallinity and eventually the glass transition temperature. PFSA (3M) ionomers were found to be investigated in only one study that involved the modification with imidazole ionic liquid [83]. The limited number of studies is probably due to their poor mechanical properties and decreased conductivities as opposed to Nafion.

In general, the strategy to improve the conductivity while maintaining the mechanical properties of the semicrystalline backbone is usually by the utilization of a multi-acid side chain. For instance, some side chains contain two sulfonyl fluoride groups that are hydrolysed to sulfonic acid. Others rely on bis(perfluooalkylsulfonyl)imide which competes with the acid strength of a perfluoroalkyl sulfonic acid. A recent development is the production of perfluoroimide acid (PFIA) ionomers with the addition of several 
bis(sulfonyl)imides added to the side chain to produce perfluoroalkyl ionene chain extended (PFICE) ionomers [84].
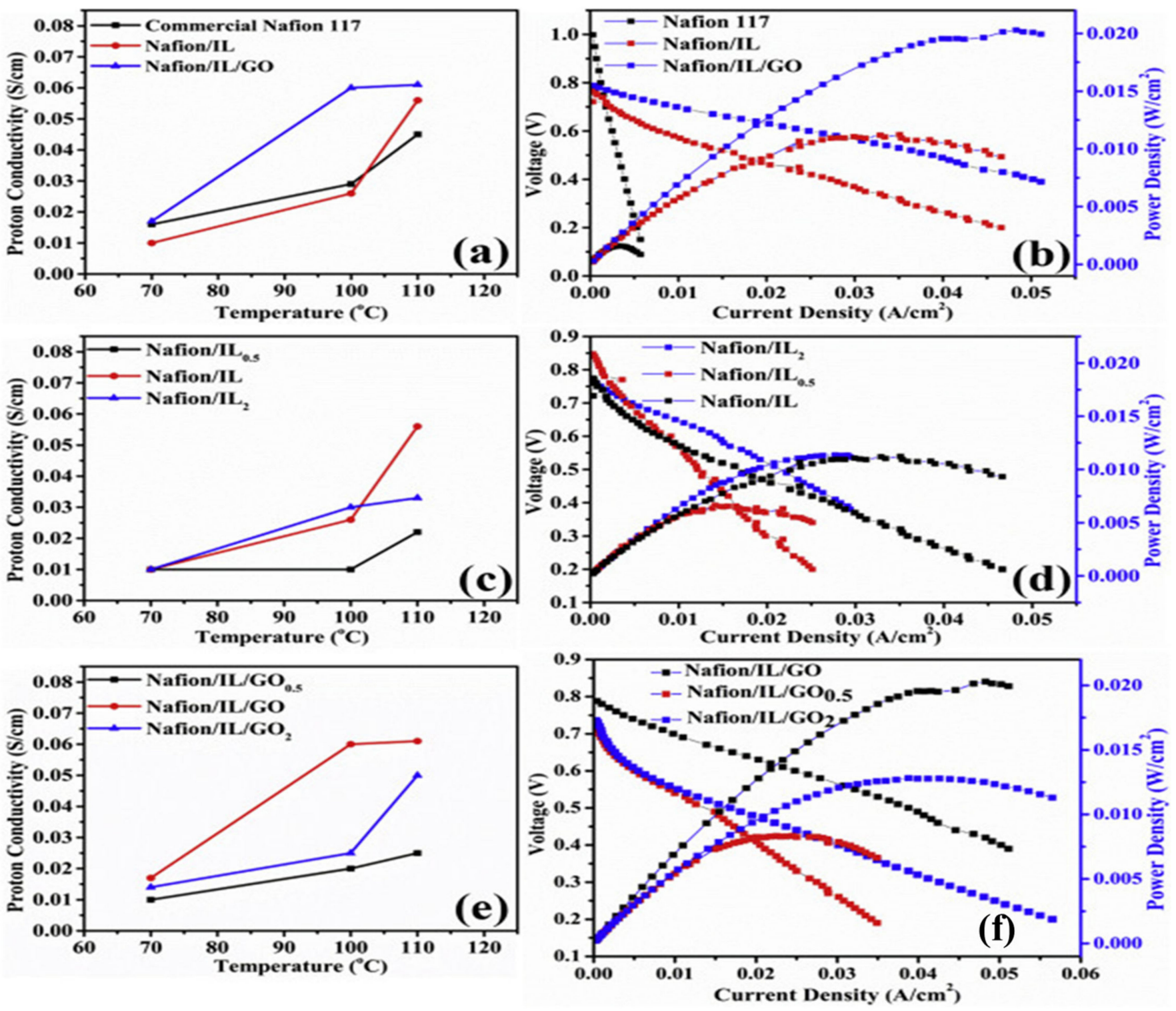

Figure 4. (a) Proton conductivities at different temperatures under anhydrous conditions. (b) I-V and power density, fuel: $\mathrm{H}_{2}$, operating conditions: $110{ }^{\circ} \mathrm{C}, 1 \mathrm{~atm}$. (c) Proton conductivities of Nafion/IL membranes at different temperatures under anhydrous conditions, (d) I-V and power density curves of Nafion/IL membranes, fuel: $\mathrm{H}_{2}$, operating conditions: $110{ }^{\circ} \mathrm{C}, 1 \mathrm{~atm}$. (e) Proton conductivity of Nafion/IL/GO membranes at different temperatures under anhydrous conditions and (f) I-V and power density curves of Nafion/IL/GO membranes, fuel: $\mathrm{H}_{2}$, operating conditions: $110^{\circ} \mathrm{C}$, $1 \mathrm{~atm}$ [82], Reproduced with permission from Elsevier, 2017.

The previous literature has summarized the recent work on Nafion/IL membranes. Researchers mainly discussed the enhancement in the properties of the Nafion membranes caused by incorporating IL. In this context, the compatibility of IL and the polymer matrix is an important consideration that affects the degree of uptake of the IL by the polymer, and consequently, the conductivity of the resulting membrane. Table 3 shows a summary of the conductivity of Nafion-based membranes. 
Table 3. Conductivity values of some Nafion-based membranes.

\begin{tabular}{|c|c|c|c|}
\hline Proton Exchange Membrne & $\begin{array}{l}\text { Proton Conductivity } \\
(\mathrm{mS} / \mathrm{cm})\end{array}$ & $\begin{array}{c}\text { Temperature } \\
\left({ }^{\circ} \mathrm{C}\right)\end{array}$ & Ref. \\
\hline Nafion 117/imidazole-imidazolium & $3-4$ & 100 & [72] \\
\hline Nafion/[BMIM][TfO] & 24 & 160 & [74] \\
\hline Nafion/[EIM][TfO] & 5.5 & 160 & [74] \\
\hline Nafion/(TEA-PSHSO $\left.{ }_{4}\right)$ & 159 & 80 & [76] \\
\hline Nafion/[MIMCM]Cl & 6 & 130 & [78] \\
\hline Nafion $/\left(\mathrm{SiO}_{2}\right)_{3.67}(\mathrm{TEA}) /(\mathrm{TEA}-\mathrm{TF})_{1.2}$ & 4.7 & 105 & [79] \\
\hline 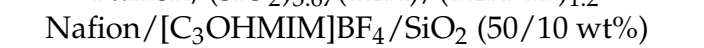 & 55 & 160 & [80] \\
\hline Nafion/[TMSPMIM]BF $4 / \mathrm{SiO}_{2}(10 \mathrm{wt} \%)$ & 375 & 90 & [81] \\
\hline Nafion/[DMBIM] $\mathrm{H}_{2} \mathrm{PO}_{4} / \mathrm{GO}(0.75 / 0.75 / 0.015 \mathrm{~g})$ & 6.1 & 110 & [82] \\
\hline
\end{tabular}

\subsubsection{Polyvinylidene Fluoride (PVDF)-Based PEM}

Polyvinylidene fluoride (PVDF) and its copolymers are widely used in polymer/IL blends. These polymers are characterized by the production of stable film possessing outstanding thermal and mechanical properties, since the presence of an amorphous region allows for a large number of liquid electrolytes. Martinella et al. [85] studied the possibility of using PVDF-HFP as a matrix polymer for EIMTFSI by investigating the thermophysical properties of polymer/IL membrane. It was demonstrated that by increasing the polymer concentration, the thermomechanical stability increases. The conductivity was measured to be $10 \mathrm{mS} / \mathrm{cm}$ for the highest IL content of $80 \mathrm{wt} . \%$. Lee et al. [86] synthesized composite membranes using 1-ethyl-3-methylimidazolium fluor hydrogenates [EMIM](FH) ${ }_{n}$ F) ILs and the fluorinated polymer compounds (S-DFBP-HFDP) and (PVDF-HFP). The conductivity of the membrane that had a weight ratio of $1 / 0.3 / 1.75$ was around $34.7 \mathrm{mS} / \mathrm{cm}$ at $130{ }^{\circ} \mathrm{C}$. Furthermore, the reported open-circuit voltage, power density, and current density were reported to be $1 \mathrm{~V}, 0.020 \mathrm{~W} / \mathrm{cm}^{2}$, and $0.06 \mathrm{~A} / \mathrm{cm}^{2}$, respectively. Gao et al. [87] examined the performance of a PVDF/IL composite membrane by varying the following cations: [Epdy], $[\mathrm{N} 1114]^{+}$, and [EMIM]. Using [N1114] $\mathrm{HSO}_{4}$, a 60 -fold increase in maximum power density was observed when compared to imidazolium-based IL. The incorporation of the protic IL and PVDF-HFP resulted in a composite membrane with a high melting temperature and a conductivity of $10 \mathrm{mS} / \mathrm{cm}$ at $140{ }^{\circ} \mathrm{C}$ [52]. Superacids have also been studied to complement the composite membranes, as they are famous proton conductors and carriers. Nair and Mohapatra [88] synthesized $\mathrm{HClO}_{4} \mathrm{SiO}_{2}$ /[dema][TfO]/PVDF-HFP composite membranes. The $\mathrm{SiO}_{2}$ particles were employed to foil the leak of [dema][TfO] from the membrane, in addition to serving as a substrate to immobilize $\mathrm{HClO}_{4}$ that was utilized for conductivity enhancement. The optimum weight percent of [dema][TfO] occurred at $80 \mathrm{wt.} \%$, where the recorded conductivities of the membrane were 0.02 and $0.6 \mathrm{mS} / \mathrm{cm}$ at 30 and $100{ }^{\circ} \mathrm{C}$, respectively. Protic IL based on amides has also been utilized. For instance, at $150{ }^{\circ} \mathrm{C}$, ITSA exhibits a high ionic conductivity of $32.6 \mathrm{mS} / \mathrm{cm}$. Xiang et al. [53] studied the physicochemical properties of ITSA/PVDF. A higher amount of PVDF decreased the conductivity. This issue was solved by the addition of PAI as a polymeric additive. Thus, an ionic conductivity of $7.5 \mathrm{mS} / \mathrm{cm}$ was achieved for PAI/PVDF (60/5 wt.\%) composite membrane.

In case of PVDF-HFP membranes, the conductivity can be enhanced by incorporating additives such as aluminium oxide particles and Polyethylene glycol (PEG) [89]. Another method is the addition of copolymers to the PVDF/IL composite membrane. Inan et al. [90] combined SPEEK with PVDF-HPF membrane and observed that the conductivity and mechanical and chemical stabilities were enhanced. Nanocomposites such as titania and silica have also been incorporated with PVDF-HPF membrane to produce similar enhancements [91,92]. Mališ et al. [93] synthesized polymer/IL membranes by mixing PVDF-HPF and Nafion polymers with BMIMTfO and EIMTfO aprotic and protic IL, respectively. The synthesized membranes were employed in fuel cells $\left(90-160^{\circ} \mathrm{C}\right)$ and compared with PBI reference fuel cells. The conductivity of the composite membranes, especially those based on EIMTfO, increased with the presence of water. For instance, adding $5 \mathrm{wt} . \%$ water in- 
creased the ionic conductivity by $170 \%$ to a value of $13.5 \mathrm{mS} / \mathrm{cm}$. The operating conditions played a vital part in the performance of the composite membranes. Under wet conditions, Nafion/BMIMTfO membranes displayed the most superior conductivity, mainly due to the weak interaction between BMIMTfO and the polymer. However, in dry conditions, the highest conductivity observed was for PVDF-HFP/EIMTfO membrane due to the late interaction between the polymer and IL, which permitted the water to stay in the structure, hence causing the superior conductivity. Nevertheless, the fuel cell did not outperform the PBI reference cell. Table 4 shows a summary of the conductivity of PVDF-based membranes.

Table 4. Conductivity values of some PVDF-based membranes.

\begin{tabular}{ccc}
\hline Proton Exchange Membrane & $\begin{array}{c}\text { Conductivity } \\
\text { (mS/cm) }\end{array}$ & $\begin{array}{c}\text { Temperature } \\
\left({ }^{\circ} \mathbf{C}\right)\end{array}$ \\
\hline PVDF-HFP/EImTFSI $(80 \mathrm{wt} /)$ & 10 & 25 \\
PVDF-HFP/s-DFBP-HFDP/[EMIm] $\left.(\mathrm{FH})_{\mathrm{n}} \mathrm{F}\right)$ & 34.7 & 130 \\
$\mathrm{HClO}_{4} \mathrm{SiO}_{2} /[\mathrm{dem}][\mathrm{TfO}] / \mathrm{PVDF}-\mathrm{HFP}$ & 0.02 & 30 \\
$\mathrm{PVDF} /[\mathrm{N} 1114]^{+} \mathrm{HSO}_{4}$ & 0.6 & 100 \\
$60 \mathrm{wt} / \mathrm{PAI} / 5 \mathrm{wt} \% \mathrm{PVDF}$ & 10 & 140 \\
$\mathrm{PVDF}-\mathrm{HFP} / \mathrm{EImTfO}$ & 7.5 & 150 \\
{$[83]$} & 13.5 & 25 \\
\hline
\end{tabular}

\subsubsection{Polybenzimidazole (PBI)-Based PEM}

PBI is commercially available and is the furthermost widely investigated and utilized polymer for high-temperature fuel-cell applications [94]. This is attributed to its low cost and good thermal and mechanical stabilities. Eguizábal et al. [95] synthesized hybrid membranes containing 1-H-3-methylimidazolium bis(trifluoromethanesulfonyl)imide [HMI][TFSI] and PBI polymer for high-temperature PEMFCs application. The optimal membrane composition achieved a conductivity of $54 \mathrm{mS} / \mathrm{cm}$ at $200{ }^{\circ} \mathrm{C}$. Van de Ven et al. [96] combined 1-H-3-methylimidazolium bis (trifluoromethanesulphonyl)imide with PBI to produce a hybrid membrane with a proton conductivity of $1.86 \mathrm{mS} / \mathrm{cm}$ at $190{ }^{\circ} \mathrm{C}$, exceeding that of Nafion 117. Ye et al. [97] produced a composite membrane based on $\mathrm{H}_{3} \mathrm{PO}_{4}$ /1-propyl-3-methylimidazolium dihydrogen phosphate $\left(\mathrm{PMIH}_{2} \mathrm{PO}_{4}\right) / \mathrm{PBI}$ for hightemperature PEMFCs. The PEMFC exhibited a proton conductivity of $2.0 \mathrm{mS} / \mathrm{cm}$ when operated at $150{ }^{\circ} \mathrm{C}$ under anhydrous conditions. Liu et al. [98] investigated the compatibility between PBI and protic IL diethylmethylammonium trifluoromethanesulfonate [dema][TfO], and developed a hybrid membrane exhibiting a conductivity of $20.73 \mathrm{mS} / \mathrm{cm}$ at $160{ }^{\circ} \mathrm{C}$. Wang et al. [99] created a cross-linked structure PBI-IPTS grafted to PBIOH30 backbone (IPTS30)/1-butyl-3-methylimidazolium dihydrogenphosphate [BMIM] ${ }_{2} \mathrm{PO}_{4}$ hybrid membranes. Due to the aromatic ring structure of the $[\mathrm{BMIM}] \mathrm{H}_{2} \mathrm{PO}_{4}$ cation, the compatibility with PBI was increased, which consequently enhanced the proton conductivity. The measured conductivity at $160{ }^{\circ} \mathrm{C}$ was $133 \mathrm{mS} / \mathrm{cm}$. Nevertheless, the presence of the cation increased the spacing between the polymeric chains leading to a reduction in the mechanical strength. For instance, compared to neat PBI membranes, a 35\% decline in tensile strength and a 30\% decline in Young's modulus were observed for $\mathrm{PBI} /[\mathrm{BMIm}] \mathrm{H}_{2} \mathrm{PO}_{4}$ (10 wt.\%).

Protic ILs have also been added to porous PBI to form composite PEMs. Eguizábal et al. [100] manufactured porous PBI treated with microporous titanosilicate (ETS-10) and combined with methylimidazolium bis(trifluoromethanesulfonyl)imide [MIM][TFSI] IL to form a PEM. The membrane achieved an in-plane conductivity of $100 \mathrm{mS} / \mathrm{cm}$ and a through-plane conductivity of $40 \mathrm{mS} / \mathrm{cm}$ at $160^{\circ} \mathrm{C}$. However, durability tests up to $500 \mathrm{~h}$ revealed a severe degradation in the proton conductivity, where values of 15 and $6 \mathrm{mS} / \mathrm{cm}$ were achieved at 150 and $200{ }^{\circ} \mathrm{C}$, respectively. In addition, the rise in the temperature resulted in the improvement of the power and current densities of the composite membranes. For example, the rise in temperature from 25 to $180{ }^{\circ} \mathrm{C}$ raised the power and current densities by $96 \%$ and $200 \%$, respectively, for compact PBI membranes at 0.5 V. Lemus et al. [101] prepared mem- 
branes utilizing porous PBI and 1-H-3-vinylimidazolium bis(trifluoromethanesulfonyl) imide [IMVH][TFSI]. Synthesis was performed using ultraviolet photopolymerization and reported conductivities were $371 \mathrm{mS} / \mathrm{cm}$ when synthesized with $2.5 \mathrm{~mol} \%$ divinylbenzene (DVB) crosslinker and $309 \mathrm{mS} / \mathrm{cm}$ when synthesized with a pre-existing PBI with $80 \%$ porosity. The stability of conductivity tests showed a decrease in conductivity for the $500 \mathrm{~h}$, and then the conductivity approximately stayed constant at a value of $250 \mathrm{mS} / \mathrm{cm}$ for both membranes. Kallem et al. [102] prepared PBI membranes infiltered with [IMVH][TFSI]. The presence of the IL repressed the transport of the proton, yet it improved both the thermal and mechanical stability. The measured conductivity at $200^{\circ} \mathrm{C}$ was around $53.3 \mathrm{mS} / \mathrm{cm}$ for a hybrid membrane PBI/IL/DVB $(0.88 / 58.5 / 1 \%)$. The tensile strength was reported to be 10.0 MPa. To enhance the membrane conductivity, [IMVH][TFSI] was added to hierarchical porous polybenzimidazole (HPBI). A conductivity of $85 \mathrm{mS} / \mathrm{cm}$ at $200{ }^{\circ} \mathrm{C}$ was obtained for a HPBI (49.5 wt.\%)/IL (58.5 wt.\%)/DVB (1\%) composite membrane [103]. Nawn et al. [104] synthesized membranes consisting of polybenzimidazole membranes (PBI4N) impregnated with zirconium dioxide $\left(\mathrm{ZrO}_{2}\right)$ nanofillers. The content of the $\mathrm{ZrO}_{2}$ filler varied between 0 and $22 \mathrm{wt} . \%$. The results show that the content of the filler plays a vital role in the performance of the PEM. For instance, as the content increased from 0 to $8 \%$, the thermal and mechanical stabilities increased. However, when increasing from 8 to $22 \%$, the opposite effect is demonstrated, where the stabilities decreased. The $\left[\mathrm{PBI} 4 \mathrm{~N}\left(\mathrm{ZrO}_{2}\right)_{0.231}\right]\left(\mathrm{H}_{3} \mathrm{PO}_{4}\right)_{13}$ membrane attained a conductivity of $104 \mathrm{mS} / \mathrm{cm}$ at $180^{\circ} \mathrm{C}$. Hybrid membranes consisting of PBI/[dema][TfO] were employed in fuel cells. The membrane showed a conductivity of $20.73 \mathrm{mS} / \mathrm{cm}$ at $160^{\circ} \mathrm{C}$. In addition, for PBI/[dema][TfO], membranes showed a conductivity reduction of 10\% (with $83 \mathrm{wt} . \%$ [dema][TfO]) and 18\% (with $80 \mathrm{wt} . \%$ [dema][TfO]) after $400 \mathrm{hr}$. Moreover, $\mathrm{PBI} /$ [dema][TfO] (83 wt.\%) membrane exhibited power density of 26.50 and $29.64 \mathrm{~mW} / \mathrm{cm}^{2}$ at $120^{\circ} \mathrm{C}$ and $140{ }^{\circ} \mathrm{C}$, respectively [98]. Xu et al. [105] prepared PEM by incorporating IL graphite oxide (ILGO) with PBI loaded with polymer acid (PA). At $175{ }^{\circ} \mathrm{C}$, the proton conductivity was measured as $35 \mathrm{mS} / \mathrm{cm}$, while the power density was measured to be $320 \mathrm{~mW} / \mathrm{cm}^{2}$. It was concluded that ILGO filler could enhance the conductivity of the PEM. Hooshyari et al. [106] developed composite membranes incorporating PBI with 1,3-di(3-methylimidazolium) propane bis (trifluoromethylsulfonyl) imide ( $\mathrm{PDC}_{3}$ ) and 1-hexyl-3-methylimidazolium bis (trifluoromethanesulfonyl) imide $\left(\mathrm{PMC}_{6}\right)$ dicationic IL. The membrane was tested for PEMFC applications under anhydrous conditions and $180{ }^{\circ} \mathrm{C}$, and $\mathrm{PBI} / \mathrm{PA} / \mathrm{PDC}_{3}$ attained an ionic conductivity and power density of $78 \mathrm{mS} / \mathrm{cm}$ and $400 \mathrm{~mW} / \mathrm{cm}^{2}$, respectively. Liu et al. [107] synthesized functional silica IL into PBIOH to produce composite membranes for PEMFC applications. Subsequent to investigating the trade-off between the conductivity and stability of the PEM based on the weight percent of the $\mathrm{IL}$, an optimum content of $5 \mathrm{wt} . \%$ was reached. At that ratio, the proton conductivity was measured as $106 \mathrm{mS} / \mathrm{cm}$ at $170{ }^{\circ} \mathrm{C}$.

For PBI/IL composite membranes, numerous studies showed that proton conductivity improved and remained stable for a longer duration. However, the presence of IL amplified the space between the polymeric chains of PBI and caused a deterioration in the intermolecular forces and mechanical strength. Table 5 shows a summary of the conductivity of PBI-based membranes. 
Table 5. Conductivity values of some PBI-based membranes.

\begin{tabular}{|c|c|c|c|}
\hline Proton Exchange Membrane & $\begin{array}{c}\text { Conductivity } \\
(\mathrm{mS} / \mathrm{cm})\end{array}$ & $\begin{array}{c}\text { Temperature } \\
\left({ }^{\circ} \mathrm{C}\right)\end{array}$ & Ref. \\
\hline $\mathrm{PBI} /[\mathrm{HMI}][\mathrm{TFSI}]$ & 54 & 200 & [95] \\
\hline [h-MIM] Ntf $2 / \mathrm{PBI}$ & 1.86 & 170 & [96] \\
\hline $\mathrm{H}_{3} \mathrm{PO}_{4} / \mathrm{PMIH}_{2} \mathrm{PO}_{4} / \mathrm{PBI}$ & 2.0 & 150 & [97] \\
\hline $\mathrm{PBI} /[$ dema] $[\mathrm{TfO}]$ & 20.73 & 160 & [98] \\
\hline $\mathrm{PBI} /[\mathrm{BMIm}] \mathrm{H}_{2} \mathrm{PO}_{4}$ & 133 & 160 & [99] \\
\hline $\mathrm{PBI} /[\mathrm{MIm}][\mathrm{TFSI}]$ & 100 & 160 & [100] \\
\hline PIL (crosslinker: $2.5 \mathrm{~mol} \%$ ) & 371 & & [101] \\
\hline PIL-PBI & 309 & & [101] \\
\hline PBI/IL/DVB (0.88/58.5/1\%) & 53.3 & 200 & [102] \\
\hline HPBI/IL/DVB (49.5/58.5/1\%) & 85 & 200 & [103] \\
\hline$\left[\mathrm{PBI} 4 \mathrm{~N}\left(\mathrm{ZrO}_{2}\right)_{0.231}\right]\left(\mathrm{H}_{3} \mathrm{PO}_{4}\right)_{13}$ & 104 & 180 & [104] \\
\hline $\mathrm{PBI} / \mathrm{PA} / \mathrm{ILGO}$ & 35 & 175 & [105] \\
\hline $\mathrm{PBI} / \mathrm{PA} / \mathrm{PDC}_{3}$ & 78 & 180 & [106] \\
\hline PBIOH-ILSi & 106 & 170 & [107] \\
\hline
\end{tabular}

\subsubsection{Sulfonated Poly (Ether Ether Ketones) (SPEEK)-Based PEM}

SPEEK membranes are widely investigated in PEMFC owing to their high thermal and chemical stability and their ability to retain water to enhance proton conductivity. Jothi and Dharmalingam [108] prepared and tested SPEEK/1-ethyl-3-methylimidazolium diethyl phosphate [EMIM][DEP] membrane by casting. Under anhydrous conditions at $145{ }^{\circ} \mathrm{C}$, an ionic conductivity of $3 \mathrm{mS} / \mathrm{cm}$ was recorded as well as a power density of $203 \mathrm{~mW} / \mathrm{cm}^{2}$ with OCP of $0.83 \mathrm{~V}$. Li et al. [109] added silicon oxide particles $\mathrm{SiO}_{x}$ to a SPEEK/[dema][TfO] membrane and investigated the resulting hybrid membranes. The addition of the $\mathrm{SiO}_{x}$ decreased the IL leakage and the inflammation degree of the membrane due to the promoted interaction between SPEEK, the IL, and siloxane. Under dry conditions, the SPEEK based membrane showed a conductivity of $20.03 \mathrm{mS} / \mathrm{cm}$ at $220^{\circ} \mathrm{C}$. Sulfonated SPEEK/[dema][TfO] IL/with modified montmorillonite clay and dema+ cation (Mmtdema) exhibited an ionic conductivity of $78 \mathrm{mS} / \mathrm{cm}$ at $70{ }^{\circ} \mathrm{C}$ [110]. Wang et al. [111] introduced mesoporous $\mathrm{SiO}_{2}$ to SPEEK/IL membranes and discovered that the presence of silica improved the IL preservation in SPEEK. For instance, SPEEK/[BMIM] $\left[\mathrm{BF}_{4}\right] / \mathrm{SiO}_{2}$ (50 wt.\%/7.5 wt.\%) membranes displayed a conductivity of $15 \mathrm{mS} / \mathrm{cm}$. Batalha et al. [112] improved the conductivity of SPEEK/[dema][TfO] composite membranes by the addition of $\mathrm{ZrO}_{2}$. The interaction between the IL and the elongated architecture of zirconia allowed for the existence of new proton transport channels. For instance, the proton conductivity of SPEEK increased from 70 to $660 \mathrm{mS} / \mathrm{cm}$ with the addition of [dema][TfO] and $6 \mathrm{wt} \%$ of $\mathrm{ZrO}_{2}$. SPEEK and [BMIm] $]^{+}$cations show excellent interaction, which allows for the retention of IL by SPEEK [113]. For example, at $160^{\circ} \mathrm{C}$ and dry conditions, the hybrid membrane SPEEK/1-butyl-3-methylimidazolium hexafluorophosphate [BMIm] $\mathrm{PF}_{6}(50 \%) / \mathrm{PA}$ (4.6 doping level) exhibited a conductivity of $30 \mathrm{mS} / \mathrm{cm}$. The durability test displayed a stable conductivity of $20 \mathrm{mS} / \mathrm{cm}$ for periods more than $600 \mathrm{hr}$. da Trindade et al. [114] aimed at enhancing the SPEEK membranes' performance by the addition of $\left(\mathrm{ImHSO}_{4}\right)$, $\left(\mathrm{MIHSO}_{4}\right.$ ) and $\mathrm{BMIHSO}_{4} \mathrm{IL}$. The conductivity increased by $50 \%$ and $30 \%$ when the membranes were doped with $5 \mathrm{wt} . \%$ of $\left(\mathrm{MIHSO}_{4}\right)$ and $\mathrm{BMIHSO}_{4}$, respectively. Moreover, for

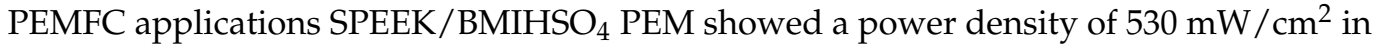
the range of 80 to $100{ }^{\circ} \mathrm{C}$. Che et al. [39] prepared a multicomponent hybrid membrane based on SPEEK, polyurethane (PU), and BMIm ${ }^{+}$IL using layer-by-layer fabrication. After 100 layers, the PEM was obtained and doped on PA to be tested for PEMFC. The PEM (SPEEK/PU/SPEEK/BMIM) ${ }_{100} / 60 \%$ PA exhibited conductivity and tensile strength of $103 \mathrm{mS} / \mathrm{cm}$ (at $160{ }^{\circ} \mathrm{C}$ ) and $2.38 \mathrm{MPa}$, respectively. Elumalai et al. [115] synthesized composite membranes based on phosphonate IL immobilised mesoporous silica SBA-15 as a filler to the SPEEK polymer matrix. In this case, the observed conductivity was $10.2 \mathrm{mS} / \mathrm{cm}$ 
with $6 \%$ SBA- $15 / \mathrm{SPEEK}$ at $140{ }^{\circ} \mathrm{C}$. At the same temperature, the mechanical strength was measured as $23 \mathrm{MPa}$, while a power density of $183 \mathrm{~mW} / \mathrm{cm}^{2}$ was also obtained. Table 6 shows the conductivity values of some SPEEK-based membranes.

Table 6. Conductivity values of some SPEEK-based membranes.

\begin{tabular}{|c|c|c|c|}
\hline Proton Exchange Membrane & Conductivity (mS/cm) & Temperature $\left({ }^{\circ} \mathrm{C}\right)$ & Ref. \\
\hline SPEEK/[EMIm][DEP] & 3 & 145 & [108] \\
\hline SPEEK $/ \mathrm{SiO}_{x} /[$ dema][TfO] (50 wt. $\%$ ), SPEEK sulfonation degree: $66 \%$ & 20 & 220 & [109] \\
\hline SPEEK/[dema][TfO]/Mmtdema, SPEEK sulfonation degree: 73\% & 78 & 70 & [110] \\
\hline $\mathrm{SPEEK}+[\mathrm{BMIm}]\left[\mathrm{BF}_{4}\right] / \mathrm{SiO}_{2}(50 / 7.5$ wt. $\%)$ & 15 & 200 & [111] \\
\hline SPEEK/[dema][TfO] and 6 wt. $\%$ of $\mathrm{ZrO}_{2}$ & 660 & 70 & [112] \\
\hline SPEEK/[BMIm] $]_{B} F_{6}(50 \%) / \mathrm{PA}$ & 30 & 160 & [113] \\
\hline$(\mathrm{SPEEK} / \mathrm{PU} / \mathrm{SPEEK} / \mathrm{BMiM})_{100} / 60 \% \mathrm{PA}$ & 103 & 160 & [39] \\
\hline $6 \%$ SBA-15/SPEEK & 10.2 & 140 & [115] \\
\hline
\end{tabular}

\subsubsection{Sulfonated Polyimide (SPI)-Based PEM}

Among other promising polymers for PEMFC is sulfonated polyimide (SPI), which exhibits high mechanical strength, high thermal stability, and low permeability. Chen et al. [116] manufactured hybrid membranes by combining 1-vinylimidazolium trifluoromethanesulfonate $[\mathrm{ImVH}][\mathrm{TfO}], 1$-methylimidazolium trifluoromethanesulfonate [MIm][TfO] IL with SPI. The resulting polymer structure is strengthened due to ionic bonds formed between the IL cations and SPI sulfonic acid groups at elevated temperatures, in turn improving the polymer's preservation of the IL, increasing the long-term stability and conductivity. Under dry conditions, SPI/[ImVH][TfO](50 wt.\%) membrane showed an ionic conductivity of $3-6 \mathrm{mS} / \mathrm{cm}$ at $120^{\circ} \mathrm{C}$. Another composite membrane consisting of SPI/[MIm] $] \mathrm{BF}_{4} / \mathrm{H}_{2} \mathrm{SO}_{4}$ was tested for fuel-cell applications [117]. The ionic conductivity achieved was $55.9 \mathrm{mS} / \mathrm{cm}$ at $180{ }^{\circ} \mathrm{C}$, however, the value deteriorated to $28.2 \mathrm{mS} / \mathrm{cm}$ after three months. Lee et al. [118] tested SPI/[dema][TfO] (67 wt.\%) membranes for PEMFC after confirming the compatibility between the IL and the polymer. Under dry conditions, the measured conductivity was $10 \mathrm{mS} / \mathrm{cm}$ at $120{ }^{\circ} \mathrm{C}$. For PEMFC performance, a current density of $240 \mathrm{~mA} / \mathrm{cm}^{2}$ and a power density of $100 \mathrm{~mW} / \mathrm{cm}^{2}$ were achieved at $80{ }^{\circ} \mathrm{C}$ under dry conditions. Chen et al. [119] synthesized the hybrid membrane SPI/[ImVH][TfO] (40 wt.\%) by employing 1,4-bis(4-aminophenoxy-2-sulfonic acid) benzenesulfonic acid (pBABTS), 3,3', 4,4'-diphenyl sulfone tetracarboxylic dianhydride (DSDA) as dianhydride, and 4, $4^{\prime}$-(9fluorenylidene) dianiline (9FDA) as diamine. Under dry conditions, the PEM attained a proton conductivity of $16 \mathrm{mS} / \mathrm{cm}$ at $120^{\circ} \mathrm{C}$. Kowsari et al. [120] synthesized PEM doped with PA and constructed on SPI/graphene oxide (GO). The GO was functionalized with $[\mathrm{MIm}]^{+}$and $\mathrm{H}_{2} \mathrm{PO}_{4}{ }^{-}$. The measured conductivity of the membrane at 160 and $120{ }^{\circ} \mathrm{C}$ were 77.2 and $124.3 \mathrm{mS} / \mathrm{cm}$, respectively.

\subsubsection{Other Polymer-Based PEM}

Zhang et al. [121] synthesized a hybrid membrane by incorporating 1-butyl-3-methylimidazolium bis(trifluoromethanesulfonyl)imide [BMIm][TFSI] IL with silicon nanorods (SNR) into poly(2,5-benzimidazole) (ABPBI) polymer. The conductivity was $10 \mathrm{mS} / \mathrm{cm}$ under a temperature range of $80-140{ }^{\circ} \mathrm{C}$. The PEMFC performance attained power densities of 150 and $280 \mathrm{~mW} / \mathrm{cm}^{2}$ at 80 and $180{ }^{\circ} \mathrm{C}$, respectively. Li et al. [122] synthesized composite membranes using sulfonated poly(arylene ether ketone sulfone) (SPAEKS) and 1-ethyl-3-methyl imidazolium phosphotungstate (PWA-IL). At $80^{\circ} \mathrm{C}$, the PEM showed an excellent proton conductivity of $127 \mathrm{mS} / \mathrm{cm}$. Figure 5 shows the variation of the temperature on the conductivity of SPAEKS-based membranes, in addition to the Arrhenius plot. Awasthi et al. [123] synthesized a hybrid membrane based on poly(arylene ether) polymer while incorporating [BMIm] $\left[\mathrm{BF}_{4}\right]$ IL. The hydrophilic length was constant at $8 \mathrm{kDa}$, while the hydrophobic length was varied $(5,8$, and $10 \mathrm{kDa})$ to produce the polymers (named as P1, P2, and P3 polymers, respectively). The increase in the hydrophobic length resulted in a decline in the proton conductivity of the membrane owing to lower water retention. 
Moreover, the IL improved the conductivity. For instance, the proton conductivity of P1 increased from 32 to $75 \mathrm{mS} / \mathrm{cm}$ when $50 \mathrm{wt}$.\% of IL was added to the PEM. Following the trend, the proton conductivity of $\mathrm{P} 2$ rose from 25 to $61 \mathrm{mS} / \mathrm{cm}$ and the proton conductivity of P3 increased by $109 \%$ with the addition of $50 \mathrm{wt} . \%$ [BMIm] $\left[\mathrm{BF}_{4}\right]$.
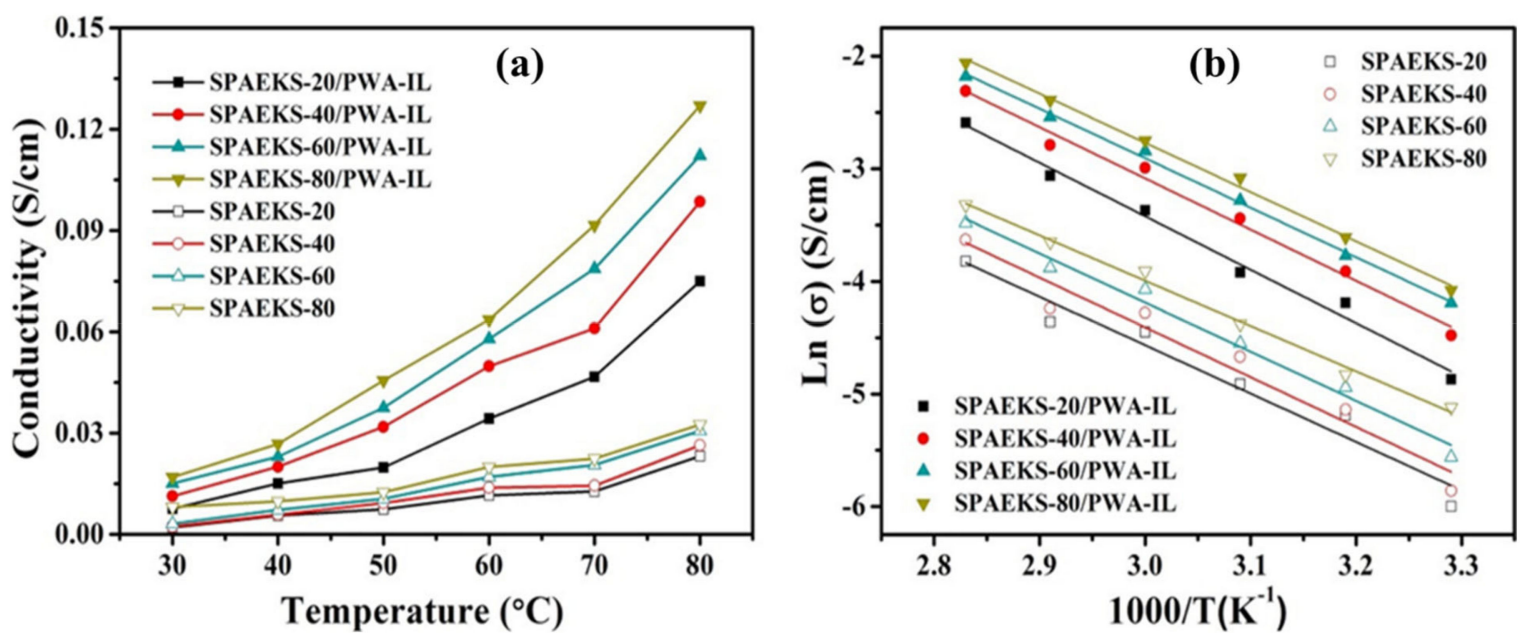

Figure 5. (a) Proton conductivity and (b) Arrhenius plot (right) of SPAEKS-X membranes and SPAEKS-X/PWA-IL membranes at different temperatures [122], Reproduced with permission from Jatindranath Maiti, et al., Composites Science and Technology; published by Elsevier, 2018.

Dahi et al. [124] synthesized hybrid membranes based on Matrimid ${ }^{\circledR}$ polymer and 1-n-butylimidazolium bis(2-ethylhexyl)phosphate [BIm][BEHP], 1-n-butylimidazolium dibutylphosphate [BIm][DBP], and 1-n-methylimidazolium dibutylphosphate [MIm][DBP] hydrophilic IL. The hybrid membranes display great stability as most of the IL is reserved in the pores of Matrimid ${ }^{\circledR}$. In addition, the viscosity of the IL deteriorated with increasing temperature, causing leakage of the IL and decreasing the conductivity. The PEM $[\mathrm{BIm}][\mathrm{DBP}] /$ Matrimid $^{\circledR}$ attained the most superior proton conductivity of $20 \mathrm{mS} / \mathrm{cm}$ when compared to its counterpart at $115^{\circ} \mathrm{C}$. Langevin et al. [55] prepared composite PEM by immersing segments of MAT14PVP7 in TEA-TF IL. The proton conductivity of the PEM at $130{ }^{\circ} \mathrm{C}$ was measured as $20 \mathrm{mS} / \mathrm{cm}$, which is higher when compared to the proton conductivity of TEA-TF/Nafion standing at $1.8 \mathrm{mS} / \mathrm{cm}$. The results also revealed that, unlike Nafion, the mechanical resistance of MAT14PVP7-based PEM is barely affected by the increase in temperature.

Zakeri et al. [125] developed and fabricated composite membranes based on [ETFEg-poly(4-VP)- $\left.\mathrm{SO}_{3} \mathrm{H}\right] \mathrm{HSO}_{4}$. At $95{ }^{\circ} \mathrm{C}$, the composite membrane revealed a staggering conductivity enhancement of $62 \%$ of that of the Nafion 112 membrane. The membrane also displayed high thermal stability. Moreover, Zakeri et al. [126] also manufactured a similar composite membrane structure of Poly(1-vinyl imidazole) grafted poly(ethylene-co-

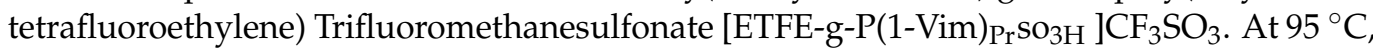
the $\mathrm{PEM}$ revealed a proton conductivity of $138 \mathrm{mS} / \mathrm{cm}$, with $96 \%$ retention at $80{ }^{\circ} \mathrm{C}$ and for $50 \mathrm{hr}$ under fully hydrated conditions. Tang et al. [127] synthesized composite membranes using adsorbed and doped [MIM][TfO] over polyacrylamide/polyethylene glycol interpenetrated (PAM/PEG IPN). With the variation in the concentration of the IL (22.84 wt.\%, $50 \mathrm{wt} . \%$ ), the conductivities attained at $150{ }^{\circ} \mathrm{C}$ were 10.37 and $17.02 \mathrm{mS} / \mathrm{cm}$, respectively. Tang et al. [128] prepared [MIM][TfO] into poly(acrylic acid)-poly(ethylene glycol) superabsorbent membranes with proton conductivities reaching $40.4 \mathrm{mS} / \mathrm{cm}$. The tests were performed under dry conditions and at a temperature of $200{ }^{\circ} \mathrm{C}$. Chopade et al. [129] studied the structure of N-ethylimidazolium bis(trifluoromethylsulfonyl)imide [EIM][TFSI]/PEO composite membranes. The thermal and mechanical stabilities were improved due to the cross-linked structured polymer. Hence, even at a high temperature of $180{ }^{\circ} \mathrm{C}$ the 
PEM with $45 \mathrm{wt} \%$ of [EIM][TFSI] exhibited a conductivity of $14 \mathrm{mS} / \mathrm{cm}$. Chu et al. [130] synthesized elastic and clear composite membranes utilizing PAMAM dendrimer-based macromolecular IL. The PEM displayed elevated thermal stability until temperatures of $350{ }^{\circ} \mathrm{C}$, and a conductivity of $12 \mathrm{mS} / \mathrm{cm}$ at $160{ }^{\circ} \mathrm{C}$ and under dry conditions. PEM based on [MIm][TfO] and [APMIm][Br]-GO with a $1.0 \mathrm{wt} . \%$ achieved a conductivity of $14.8 \mathrm{mS} / \mathrm{cm}$ at $160{ }^{\circ} \mathrm{C}$ [131].

Thanganathan and Nogami [132] improved the properties of poly(vinyl alcohol) (PVA) membranes by incorporating 1-butyl-3-methylimidazolium Bis (trifluoromethanesulfonyl)imide (BMITFSI) and 1-ethyl-3-methylimidazolium tetrafluoroborate $\left(\mathrm{EMI}^{\left.-\mathrm{BF}_{4}\right)}\right.$ ILs. Silica was incorporated as well to improve the stability and conductivity of the PEM. The hybrid membranes displayed conductivities of a maximum of $0.58 \mathrm{mS} / \mathrm{cm}$ at $60{ }^{\circ} \mathrm{C}$. Yang et al. [133] synthesized composite membranes based on (PVA)-Citric Acid (CA)-IL for PEMFC applications. The tested results proved that PVA-CA-IL membranes show excellent performance under anhydrous conditions. Furthermore, PVA-CA-EAN (1:0.05:0.4 molar ratio) exhibited the most superior proton conductivity of $7.8 \mathrm{mS} / \mathrm{cm}$ at $140{ }^{\circ} \mathrm{C}$. Wu et al. [134] studied the effect of poly(phenylene oxide) (PPO)/methylimidazole (MeIM) composite membranes on the performance of a PEMFC. At $30{ }^{\circ} \mathrm{C}$, the PPO/MeIM membrane recorded a proton conductivity of $67.9 \mathrm{mS} / \mathrm{cm}$ in addition to a mechanical strength of $4.8 \mathrm{MPa}$ at a molar ratio of 4:10 Moreover, without the additional humidification the PEMFC displayed a power density of $260 \mathrm{~mW} / \mathrm{cm}^{2}$ at $160{ }^{\circ} \mathrm{C}$.

The proton conductivity of Zirconium phosphate $(\mathrm{ZrP})$ powder has been examined and composite membranes prepared from $\mathrm{ZrP}$ and porous polytetrafluoroethylene (PTFE) with and without mineral acids have been also investigated as electrolytes for direct hydrocarbon fuel cells that operate at high temperatures [135-138]. Moreover, Mohammed et al. [139] synthesized PEM based on ZrP and imidazolium-based IL for high-temperature fuel-cell applications. Five imidazolium based ILs were tested: 1-ethyl-3-methylimidazolium ethyl sulfate [EMIM][ESO 4 , 1-butyl-3-methylimidazolium dicyanamide [BMIM][DCA], 1-butyl-3-methylimidazolium triflate [BMIM][TFA], 1-ethyl3-methylimidazolium acetate [EMIM][AC], 1-butyl-3-methylimidazolium Trifluoroacetic [BMIM][TFA]. ZrP/[EMIM][ESO $]_{4}$ recorded the most superior proton conductivity of $22.6 \mathrm{mS} / \mathrm{cm}$ when compared to its imidazolium-based IL counterparts. The reported results showed better performance than Nafion membranes, which highlights the great potential of ZrP-based PEM. A similar study by Al-Othman et al. [140] reported on the synthesis of composite membranes based on $\mathrm{ZrP}$ polymer, imidazolium-based IL, and glycerol supported on PTFE. The ZrP/[EMIM][SO 4$] /$ GLY/PTFE membrane was tested for PEMFC applications and demonstrated a proton conductivity of $70 \mathrm{mS} / \mathrm{cm}$ at $200{ }^{\circ} \mathrm{C}$. Ortiz-Martínez et al. [141] copolymerized 1-(4-sulphobutyl)-3-vinylimidazolium trifluoromethanesulphonate $\left[\mathrm{HSO}_{3}{ }^{-}\right.$BVIm] [TfO] IL with methyl methacrylate MMA and perfluoro-3,6-dioxa-4-methyl-7-octene sulfonyl fluoride (hPFSVE) to form PILs for PEMFC

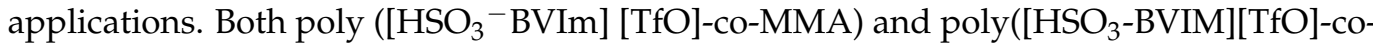
hPFSVE) electrolyte membranes offered high conductivity in the range of $(1-10 \mathrm{mS} / \mathrm{cm})$ for wet and dry conditions. The performance of membranes was improved, showing the promising prospects of these PILs as PEM, with power outputs up to $45 \mathrm{~mW} / \mathrm{cm}^{2}$. Figure 6 shows the performance of the PEMFC for various mall ratios. 

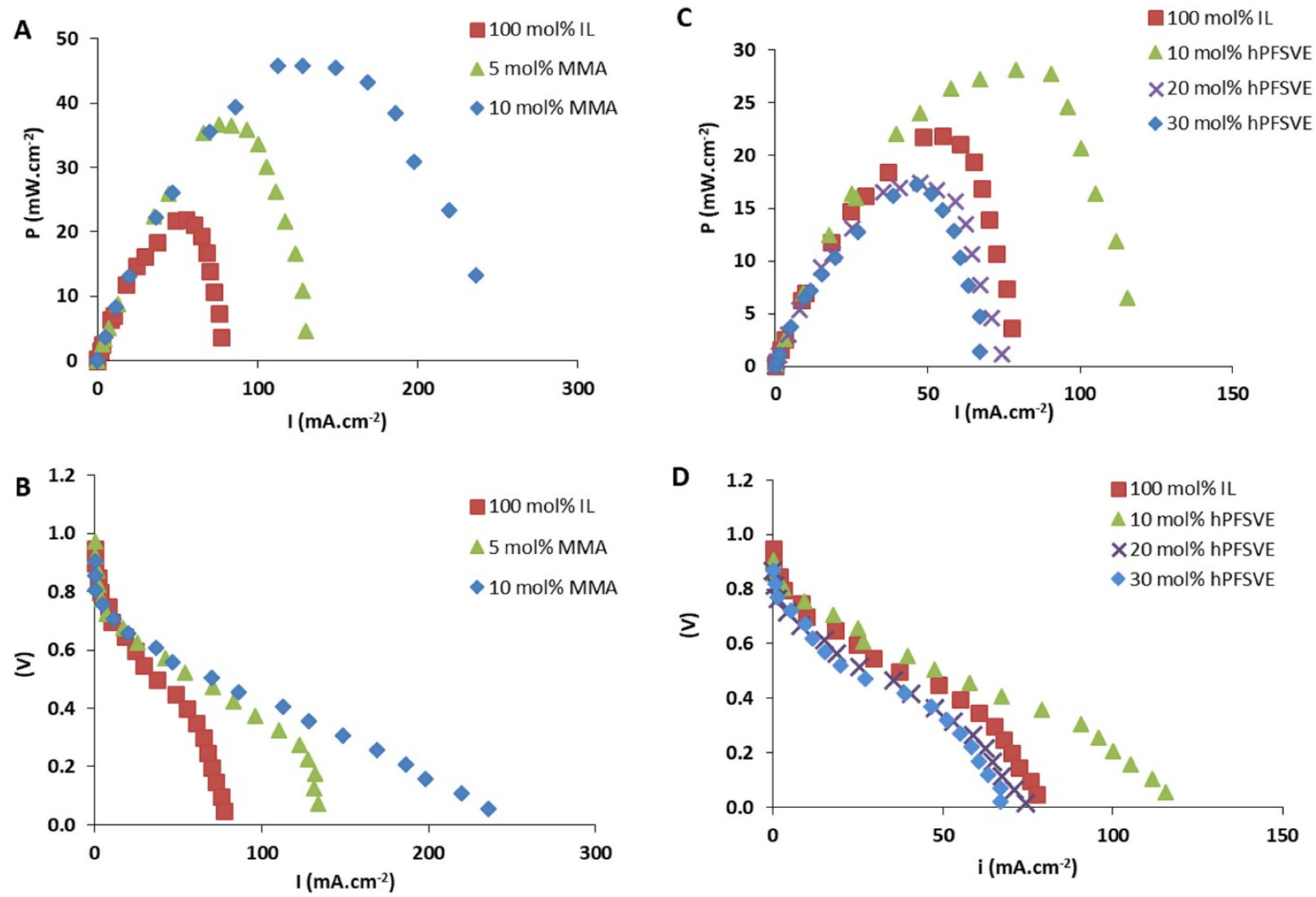

Figure 6. (A,C) Power curves and (B,D) polarization curves for PEMFC membranes based on poly(ILco-hPFSVE), poly([IL-co-MMA), and poly(IL) [141]. Reproduced with permission from Elsevier, 2019.

Zhu et al. [142] prepared PILs with precursors of 1,3,5-tris(1-imidazolyl)benzene (TIB) and incorporated them into poly (2,6-dimethyl phenylene oxide) (QPPO) polymer matrix to produce hybrid PEM. The resulting TIB/QPPO hybrid membranes exhibited decent thermal stability, suitable mechanical properties, and improved conductivity and fuel-cell performance. For instance, the highest conductivity and fuel-cell performance recorded were $55 \mathrm{mS} / \mathrm{cm}$ and $168.9 \mathrm{~mW} / \mathrm{cm}^{2}$ at $80^{\circ} \mathrm{C}$, respectively. Eisa et al. [143] prepared PEMFC based on polyaniline (PANI), 1-Hexyl-3- Methylimidazolium Tricyanomethanide IL, and ZrP. The proposed PEMFC with (50:50 mg) PANI/ZrP and $3.7 \mathrm{wt} . \%$ IL showed a promising ionic conductivity of $20 \mathrm{mS} / \mathrm{cm}$ at room temperature. Ka'ki et al. [40] synthesized and evaluated nanocomposite PEMFC based on calcium phosphate (CP) and ILs. PEMFC with $\mathrm{CP} / \mathrm{PTFE} /[\mathrm{HMIM}]\left[\mathrm{C}_{4} \mathrm{~N}_{3}{ }^{-}\right.$] composite membranes possessed a proton conductivity of $100 \mathrm{mS} / \mathrm{cm}$ at room temperature and $3.14 \mathrm{mS} / \mathrm{cm}$ at $200{ }^{\circ} \mathrm{C}$. Table 7 lists the conductivity values of polymer-based membranes.

Sulfonated polyphenylene oxide (SPPO) has also been investigated as a polymer matrix for PEMFCs. Fu et al. [144] prepared several SPPO membranes for fuel-cell applications. The membranes showed a proton conductivity of $94 \mathrm{mS} / \mathrm{cm}$ at $25^{\circ} \mathrm{C}$, which is comparable to that of Nafion 117. Yang et al. [145] prepared SPPO-based membranes in $\mathrm{N}$-methyl-2-pyrrolidone solution for PEM applications. The resulting membranes exhibited a proton conductivity of $11.6 \mathrm{mS} / \mathrm{cm}$ at $25^{\circ} \mathrm{C}$, which is also comparable to that of Nafion 112. Liu et al. [146] presented a method to stabilize poly(methyl-methylcrylate) (PMMA)grafted magnetic nanoparticles with sulfonated polystyrene (SPS) in IL/cosolvent mixtures. The experimental results displayed that the highest ionic conductivity in the range of $30 \mathrm{mS} / \mathrm{cm}$ occurred while dissolving PMMA-PSS in acetonitrile and ILs. Zhang et al. [147] studied the enhancement of SPAEKS-based PEMS by the introduction of [EMIM][N(Tf $)_{2}$ ] IL, MIL-100 metal organic framework, and phosphotungstic acid (HPW). Membranes based on SPAEKS with HPW-ILs@MIL-100 showed an outstanding conductivity of $138 \mathrm{mS} / \mathrm{cm}$ at $100{ }^{\circ} \mathrm{C}$. Wang et al. [148] synthesized a series of sulfonated poly(arylene ether ketone 
ketone sulfone) SPAEKKS polymers for PEMFC applications. The resulting membranes reported a proton conductivity of $32 \mathrm{mS} / \mathrm{cm}$ at $80^{\circ} \mathrm{C}$, which is comparable to Nafion 117.

Table 7. Conductivity values of some polymer-based membranes.

\begin{tabular}{|c|c|c|c|}
\hline Proton Exchange Membrane & $\begin{array}{c}\text { Conductivity } \\
(\mathrm{mS} / \mathrm{cm})\end{array}$ & $\begin{array}{c}\text { Temperature } \\
\left({ }^{\circ} \mathrm{C}\right)\end{array}$ & Ref. \\
\hline ABPBI/SNR/[BMIm][TFSI] & 10 & 80 & [121] \\
\hline SPAEKS/PWA & 127 & 80 & [122] \\
\hline Poly (arylene ether)/[BMIm] $\left[\mathrm{BF}_{4}\right]$ & 75 & 70 & [123] \\
\hline$[\mathrm{BIm}][\mathrm{DBP}] /$ Matrimid $^{\circledR}$ & 20 & 115 & [124] \\
\hline MAT14PVP7/TEA-T & 20 & 130 & [55] \\
\hline [ETFE-g-poly(4-VP)-SO 3 H] $\mathrm{HSO}_{4}$ & 259 & 90 & [125] \\
\hline [ETFE-g-P(1-Vim) $\left.{ }_{\mathrm{PrSO}} \mathrm{H}\right] \mathrm{CF}_{3} \mathrm{SO}_{3}$ & 138 & 95 & [126] \\
\hline$[\mathrm{MIm}][\mathrm{TfO}] / \mathrm{PAM} / \mathrm{PEG}$ IPN (22.84 wt $\%)$ & 10.37 & 150 & [127] \\
\hline [MIm][TfO]/PAM/PEG IPN (50 wt \%) & 17.02 & 150 & [127] \\
\hline$[\mathrm{MIm}][\mathrm{TfO}] / \mathrm{PAA}$ & 19.4 & 200 & [128] \\
\hline$[\mathrm{MIm}][\mathrm{TfO}] / \mathrm{PEG}$ & 40.4 & 200 & [128] \\
\hline$[$ EIm $][$ TFSI $] / \mathrm{PEO}$ & 14 & 180 & [129] \\
\hline$[\mathrm{MIm}][\mathrm{TfO}]$ and [APMIm][BR]-GO & 14.8 & 160 & [131] \\
\hline PVA/PMA/SiO $2 /$ BMITFSI & 0.83 & 60 & [132] \\
\hline $\mathrm{PVA} / \mathrm{PMA} / \mathrm{SiO}_{2} / \mathrm{EMI}^{-\mathrm{BF}_{4}}$ & 0.58 & 60 & [132] \\
\hline PVA-CA-EAN (1:0.05:0.4 molar ratio) & 7.8 & 140 & [133] \\
\hline $\mathrm{PPO} / \mathrm{MeIM}$ & 67.9 & 30 & [134] \\
\hline $\mathrm{ZrP} /[\mathrm{EMIM}]\left[\mathrm{ESO}_{4}\right.$ & 22.6 & 200 & [139] \\
\hline $\mathrm{ZrP} /[\mathrm{EMIM}]\left[\mathrm{SO}_{4}\right] / \mathrm{GLY} / \mathrm{PTFE}$ & 70 & 200 & [140] \\
\hline TIB/QPPO & 55 & 80 & [142] \\
\hline PANI/ZrP/IL (3.7 wt\%) & 20 & 25 & [143] \\
\hline $\mathrm{CP} / \mathrm{PTFE} /[\mathrm{HMIM}]\left[\mathrm{C}_{4} \mathrm{~N}_{3}{ }^{-}\right]$ & 100 & 25 & {$[40]$} \\
\hline $\mathrm{CP} / \mathrm{PTFE} /[\mathrm{HMIM}]\left[\mathrm{C}_{4} \mathrm{~N}_{3}{ }^{-}\right]$ & 3.14 & 200 & [40] \\
\hline SPPO & 94 & 25 & [144] \\
\hline SPPO/N-methyl-2-pyrrolidone & 11.6 & 25 & [145] \\
\hline SPAEKS/HPW-ILs@MIL-100 & 138 & 100 & [147] \\
\hline SPAEKKS & 32 & 80 & [148] \\
\hline
\end{tabular}

\section{IL/Polymer PEM: Challenges and Future Work}

The durability of PEM membranes is one of the most critical properties. It is affected by various factors that can cause membranes' degradation either in mechanical, thermal, or chemical modes $[149,150]$. The mechanical degradation appears in the form of pinholes and cracks that are usually present as a result of manufacturing defects and can be detected in the early life of the PEMFC. The presence of cracks and pinholes lead to fuel crossover, hence, a combustion reaction resulting from the reaction of hydrogen and oxygen, instead of an electrochemical reaction. This leads to a severe safety risk [151]. The delamination of the membrane-electrode interface is another issue that has a direct influence on membrane durability of the PEMFCs. Delamination is a result of stress cycling and causes severe interfacial resistance, thus, an intense performance drop. The high-temperature operation is another serious issue that affects the durability of the PEM, as material decomposes around $280{ }^{\circ} \mathrm{C}$ for PFSA membranes [151]. Another issue caused by thermal degradation is the membrane thinning. The membrane's material decomposition causes a reduction in the thickness of the membrane. Membrane thinning can lead to fuel crossover and electrical short circuits. The oxidization of the platinum catalyst under fuel-cell conditions is another important issue in fuel-cell materials' durability [150].

In order for PEMFC technology to outperform the current technologies, the durability and performance ought to be increased, while decreasing the cost. The performance of the PEMFC highly depends on the power densities obtained. Therefore, an improvement in the conductivity of the PEM and a decline in the electrodes' polarization losses will surely improve the power densities. Moreover, the PEM should meet the requirement of 
PEMFC application, especially the required stable performance for high-temperature PEM. Thus, the electrode/membrane interface (whether electrically or chemically) will affect the fuel-cell performance. For instance, the reduced interface will result in elevated electronic resistance and low utilization.

The main challenge facing polymerized IL membranes is the compatibility of ILs with the matrix polymers and the organic-inorganic fillers. There has been a clear compromise between the conductivity and the mechanical strength of the composite materials. Another major issue is the long-term thermal and mechanical stability of the composite membranes, especially under high-temperature PEMFC operation. The leakage of the IL from the membrane structure is another challenge faced in PEMFC operation. Moreover, PEM doped in acids to increase the conductivity should possess the ability to hold the acid, which in turn will improve the long-term stability of the PEM.

Research in the coming future must be directed towards studying several IL cations such as pyrrolidinium or triazolium, since all the present research fixated on ammonium and imidazolium-based IL has been exhausted. Poly ILs have the potential to provide a feasible alternative for conventional and commercially available polymers. Poly ILs are known for their excellent conductivity and high thermal stability, as well as their environmentally friendly and low-cost synthesis compared to Nafion [152]. Further, poly ILs are considered a promising replacement for IL as they are more stable and safe, possess better mechanical properties, and most importantly they offer a solution for the leakage issues. Hence, future research should be dedicated to investigating the employment of poly IL in PEMFC. The molecular and morphological structures of the PEM ought to be studied using molecular dynamics and orbital simulation, as they provide information that cannot be attained experimentally. Research should also focus on studying the proton conduction mechanisms inside the PEM to enable the design of IL-polymer membranes with optimized performance.

\section{Conclusions}

This review article provided an overview of the employment of polymerized ILs in PEMFC applications. The review focused on the preparation of composite membranes utilizing the most commonly used polymers in PEM: Nafion, PVDF, PBI, SPEEK, and SPI, in addition to other polymers incorporated with ILs. A small section on the methods and techniques available for the synthesis of polymer/IL membranes was also presented. The addition of some carefully selected ILs to the polymer matrix improved the conductivity, thermal and mechanical stability, as well as the mechanical strength of pristine PEM. In terms of conductivity, PBI-based composite membranes revealed the highest conductivity and longest stability when compared to their polymer counterparts. For instance, conductivities of 371 and $309 \mathrm{mS} / \mathrm{cm}$ were recorded for PIL $2.5 \mathrm{~mol} \%$ CL and PIL-PBI composite membranes. The same membranes exhibited a stable conductivity larger than $250 \mathrm{mS} / \mathrm{cm}$ and lasted for more than 40 days. With respect to the mechanical properties, it was concluded that protic ILs might produce a plasticizing effect, which causes a decline in the ionic domains' dipolar interactions. A prominent method to overcome the issue is polymer cross-linking. In that aspect, SPEEK-based polymers exhibited the highest mechanical strength. For example, crosslinking glycerol or glycol with SPEEK to prepare TFAPA/SPEEK improved the membrane's mechanical strength. The paper also highlighted the current challenges facing the employment of polymer/ILs in PEMFC and suggested various paths for the development of research on polymerized ILs and their application in PEMFC.

Author Contributions: Conceptualization, A.A.-O. and M.T.; methodology, Adnan Alashkar, A.A.-O. and M.T.; validation, A.A.; formal analysis, A.A., A.A.-O., M.T. and M.Q.; investigation, A.A. and A.A.-O.; writing-original draft preparation, A.A., A.A.-O., M.T. and M.Q.; writing-review and editing, A.A., A.A.-O., M.T. and M.Q.; visualization, A.A.-O. and M.T.; supervision A.A.-O. All authors have read and agreed to the published version of the manuscript. 
Funding: The APC was funded by the American University of Sharjah open access program (OAP), OAP22-CEN-073.

Institutional Review Board Statement: Not applicable.

Informed Consent Statement: Not applicable.

Data Availability Statement: Data will be available on request.

Acknowledgments: The authors would like to acknowledge the financial support from the open access program (OAP) at the American University of Sharjah through grant \#OAP22-CEN-073.

Conflicts of Interest: The authors declare no conflict of interest.

\section{Abbreviations}

[2-FPy]TF:

[2-sea][TfO]:

9FDA:

ABPBI:

$\mathrm{BG}-\mathrm{BF}_{4}$ :

[BIm][BEHP]:

[BIm][DBP]:

$\mathrm{BMIHSO}_{4}$ :

[BMIM][DCA]

[BMIm] $\mathrm{H}_{2} \mathrm{PO}_{4}$ :

[BMIM][TFA]:

[BMIM][TFA]:

[BMIm][TfO]:

[BMIm] $\left[\mathrm{BF}_{4}\right]$ :

[BMIm] $\mathrm{PF}_{6}$ :

(Btmps)/HN(Tf $)_{2}$ :

[bzlm][TFSI]:

$\left[\mathrm{C}_{2} \mathrm{H}_{3} \mathrm{~N}_{3}\right] /\left[\mathrm{CH}_{3} \mathrm{SO}_{3} \mathrm{H}\right]$ :

$\left[\mathrm{C}_{2}\right.$ mim $][\mathrm{TFSI}]$ :

$\left[\mathrm{C}_{3} \mathrm{OHmim}\right] \mathrm{BF}_{4}$ :

$\mathrm{CF}_{3} \mathrm{SO}_{3}$ :

CL:

$\mathrm{CP}$ :

[dema] $\mathrm{HSO}_{4}$ :

[dema][TfO]:

[dema][TFSA]:

[DMBIm] $\mathrm{H}_{2} \mathrm{PO}_{4}$ :

[DMEIm] $\mathrm{H}_{2} \mathrm{PO}_{4}$ :

[DEMET][TFSI]:

DSDA:

DTA $^{+}$:

DVB:

[EIm][TfO]:

[EIm][TFSI]:

[Emim]:

[EMIM][AC]:

[EMIM] $\left[\mathrm{BF}_{4}\right]$ :

[EMIm][DEP]: 2-fluoropyridinium triflate

2-Sulfoethylammonium trifluoromethanesulfonate

4,4'-(9-fluorenylidene) dianiline

Poly(2,5-benzimidazole)

N-butylguanidinium tetrafluoroborate

1-n-butylimidazolium bis(2-ethylhexyl)phosphate

1-n-butylimidazolium dibutylphosphate

1-butyl-3-methylimidazolium hydrogen sulfate

1-butyl-3-methylimidazolium dicyanamide

1-butyl-3-methylimidazolium dihydrogenphosphate

1-butyl-3-methylimidazolium triflate

1-butyl-3-methylimidazolium Trifluoroacetic

1-butyl-3-methylimidazolium trifluoromethanesulfonate

1-butyl-3-methylimidazolium tetrafluoroborate

1-butyl-3-methylimidazolium hexafluorophosphate

3-(1-butyl-1H-imidazol-3-ium-3-yl) propane-1- sulfonate

1,1,1-Trifluoro-N-(trifluoromethylsulfonyl) methanesulfoneamide

Benzimidazolium bis(trifluoromethanesulphonyl)imide

1H-1,2,4-triazole/methanesulfonic acid

Methylmethacrylatein1-ethyl-3-methylimida-

zolium bis(trifluoromethanesulfonyl)imide

1-(3-hydroxypropyl)-3-methylimidazolium tetrafluoroboride

Trifluoromethanesulfonate

Crosslinker

Calcium phosphate

Diethylmethylammonium hydrogensulfate

Diethylmethylammonium trifluoromethanesulfonate

Diethylmethylammonium bis(trifluoromethylsulfonyl) amide

2,3 dimethyl-1-butylimidazolium dihydrogen phosphate

2,3-dimethyl-1-ethylimidazolium dihydrogenphosphate

$\mathrm{N}, \mathrm{N}$-diethyl-N-methyl-N-(2-methoxyethyl) ammonium

bis (trifluoromethanesulfonyl) imide

$3,3^{\prime}, 4,4^{\prime}$-diphenyl sulfone tetracarboxylic dianhydride

n-dodecyltrimethylammonium

Divinylbenzene

1-ethylimidazolium trifluoromethanesulfonate

N-ethylimidazolium bis(trifluoromethylsulfonyl)imide

1-ethyl-3-methylimidazolium cation

1-ethyl-3-methylimidazolium acetate

1-ethyl-3-methylimidazolium tetrafluoroborate

1-ethyl-3-methylimidazolium diethyl phosphate 


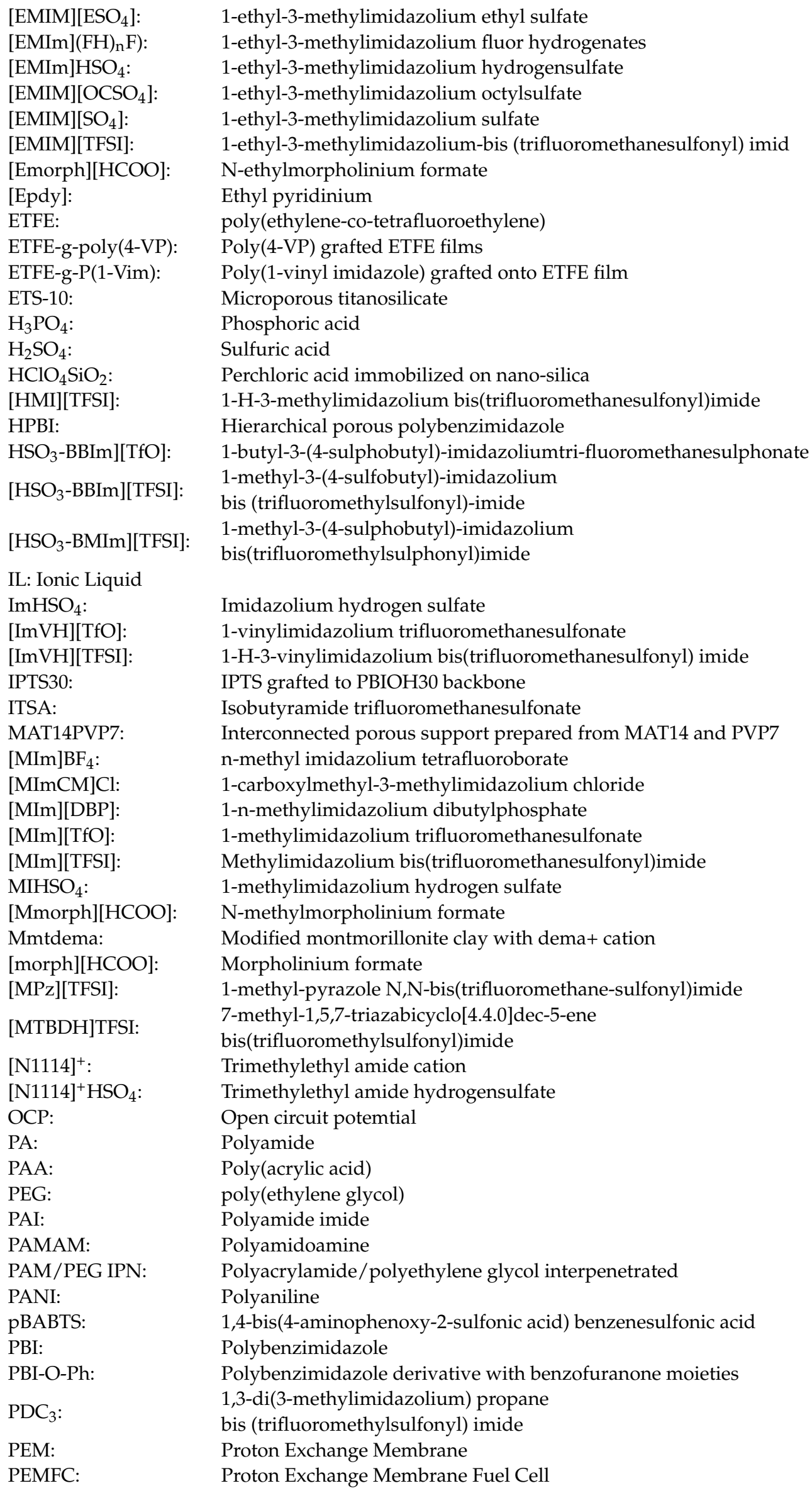




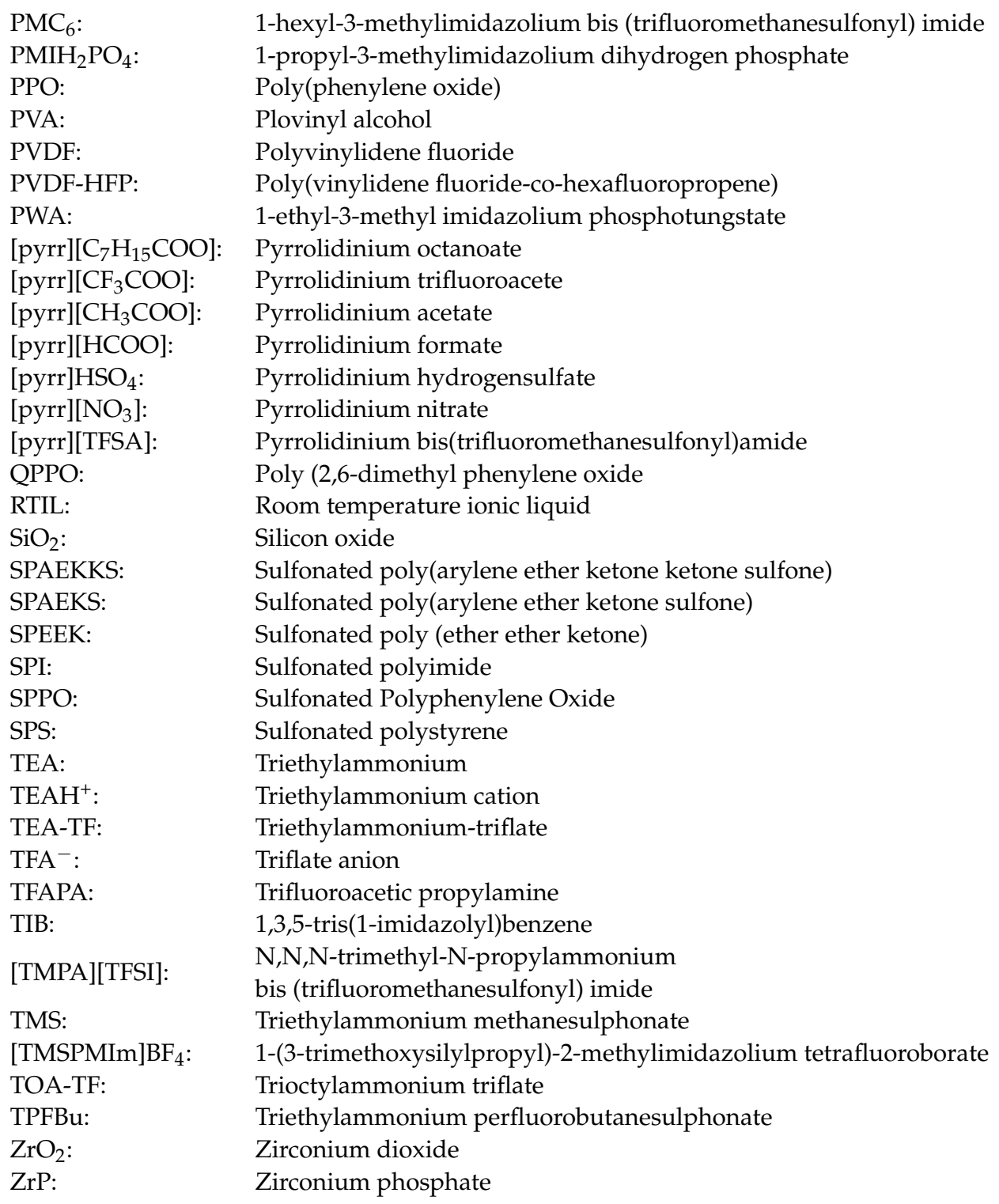

\section{References}

1. Jayakumar, A.; Chalmers, A.; Lie, T.T. Review of prospects for adoption of fuel cell electric vehicles in New Zealand. IET Electr. Syst. Transp. 2017, 7, 259-266. [CrossRef]

2. Tawalbeh, M.; Al-Othman, A.; Assad, M.E.H. Graphene oxide-Nafion composite membrane for effective methanol crossover reduction in passive direct methanol fuel cells. In Proceedings of the 2018 5th International Conference on Renewable Energy: Generation and Applications (ICREGA), Al Ain, United Arab Emirates, 25-28 February 2018; pp. 192-196. [CrossRef]

3. Mohammed, H.; Al-Othman, A.; Nancarrow, P.; Tawalbeh, M.; El Haj Assad, M. Direct hydroCarbon fuel cells: A promising technology for improving energy efficiency. Energy 2019, 172, 207-219. [CrossRef]

4. Martis, R.; Al-Othman, A.; Alkasrawi, M.; Tawalbeh, M. Fuel cells for carbon capture and power generation: Simulation studies. Int. J. Hydrog. Energy 2021, 46, 6139-6149. [CrossRef]

5. İnci, M.; Türksoy, Ö. Review of fuel cells to grid interface: Configurations, technical challenges and trends. J. Clean. Prod. 2019, 213, 1353-1370. [CrossRef]

6. Yu, F.; Han, T.; Wang, Z.; Xie, Y.; Wu, Y.; Jin, Y.; Yang, N.; Xiao, J.; Kawi, S. Recent progress in direct carbon solid oxide fuel cell: Advanced anode catalysts, diversified carbon fuels, and heat management. Int. J. Hydrog. Energy 2021, 46, 4283-4300. [CrossRef]

7. Ogungbemi, E.; Wilberforce, T.; Ijaodola, O.; Thompson, J.; Olabi, A.G. Review of operating condition, design parameters and material properties for proton exchange membrane fuel cells. Int. J. Energy Res. 2021, 45, 1227-1245. [CrossRef]

8. Tawalbeh, M.; Al-Othman, A.; Singh, K.; Douba, I.; Kabakebji, D.; Alkasrawi, M. Microbial desalination cells for water purification and power generation: A critical review. Energy 2020, 209, 118493. [CrossRef]

9. Wilberforce, T.; Ijaodola, O.; Emmanuel, O.; Thompson, J.; Olabi, A.; Abdelkareem, M.; Sayed, E.; Elsaid, K.; Maghrabie, H. Optimization of Fuel Cell Performance Using Computational Fluid Dynamics. Membranes 2021, 11, 146. [CrossRef] 
10. Kim, A.R.; Park, C.J.; Vinothkannan, M.; Yoo, D.J. Sulfonated poly ether sulfone/heteropoly acid composite membranes as electrolytes for the improved power generation of proton exchange membrane fuel cells. Compos. Part B Eng. 2018, 155, $272-281$. [CrossRef]

11. Ryu, S.K.; Kim, A.R.; Vinothkannan, M.; Lee, K.H.; Chu, J.Y.; Yoo, D.J. Enhancing Physic Chemical Properties and Single Cell Performance of Sulfonated Poly(arylene ether) (SPAE) Membrane by Incorporation of Phosphotungstic Acid and Graphene Oxide: A Potential Electrolyte for Proton Exchange Membrane Fuel Cells. Polymers 2021, 13, 2364. [CrossRef]

12. Tellez-Cruz, M.M.; Escorihuela, J.; Solorza-Feria, O.; Compañ, V. Proton Exchange Membrane Fuel Cells (PEMFCs): Advances and Challenges. Polymers 2021, 13, 3064. [CrossRef]

13. Sun, X.; Simonsen, S.; Norby, T.; Chatzitakis, A. Composite Membranes for High Temperature PEM Fuel Cells and Electrolysers: A Critical Review. Membranes 2019, 9, 83. [CrossRef]

14. Cano, Z.P.; Banham, D.; Ye, S.; Hintennach, A.; Lu, J.; Fowler, M.; Chen, Z. Batteries and fuel cells for emerging electric vehicle markets. Nat. Energy 2018, 3, 279-289. [CrossRef]

15. Ogungbemi, E.; Wilberforce, T.; Ijaodola, O.; Thompson, J.; Olabi, A.G. Selection of proton exchange membrane fuel cell for transportation. Int. J. Hydrog. Energy 2021, 46, 30625-30640. [CrossRef]

16. Alaswad, A.; Omran, A.; Sodre, J.R.; Wilberforce, T.; Pignatelli, G.; Dassisti, M.; Baroutaji, A.; Olabi, A.G. Technical and Commercial Challenges of Proton-Exchange Membrane (PEM) Fuel Cells. Energies 2020, 14, 144. [CrossRef]

17. Nancarrow, P.; Al-Othman, A.; Mital, D.K.; Döpking, S. Comprehensive analysis and correlation of ionic liquid conductivity data for energy applications. Energy 2021, 220, 119761. [CrossRef]

18. Díaz, M.; Ortiz, A.; Ortiz, I. Progress in the use of ionic liquids as electrolyte membranes in fuel cells. J. Membr. Sci. 2014, 469, 379-396. [CrossRef]

19. Elwan, H.A.; Mamlouk, M.; Scott, K. A review of proton exchange membranes based on protic ionic liquid/polymer blends for polymer electrolyte membrane fuel cells. J. Power Sources 2021, 484, 229197. [CrossRef]

20. Miyatake, K.; Watanabe, M. Recent progress in proton conducting membranes. Electrochem. Commun. 2005, 73, 12-19. [CrossRef]

21. Al-Othman, A.; Tawalbeh, M.; Temsah, O.; Al-Murisi, M. Industrial Challenges of MOFs in Energy Applications. In Encyclopedia of Smart Materials; Elsevier: Amsterdam, The Netherlands, 2022; pp. 535-543.

22. Muto, F.; Oshima, A.; Kakigi, T.; Mitani, N.; Matsuura, A.; Fujii, K.; Sato, Y.; Li, J.; Washio, M. Synthesis and characterization of PEFC membranes based on fluorinated-polymer-alloy using pre-soft-EB grafting method. Nucl. Instrum. Methods Phys. Res. 2007, 265, 162-167. [CrossRef]

23. Wang, J.; Yue, Z.; Economy, J. Preparation of proton-conducting composite membranes from sulfonated poly (ether ether ketone) and polyacrylonitrile. J. Membr. Sci. 2007, 291, 210-219. [CrossRef]

24. Seng, L.K.; Masdar, M.S.; Shyuan, L.K. Ionic Liquid in Phosphoric Acid-Doped Polybenzimidazole (PA-PBI) as Electrolyte Membranes for PEM Fuel Cells: A Review. Membranes 2021, 11, 728. [CrossRef]

25. Li, S.; Peng, C.; Shen, Q.; Wang, C.; Cheng, Y.; Yang, G. Impact of Membrane Phosphoric Acid Doping Level on Transport Phenomena and Performance in High Temperature PEM Fuel Cells. Membranes 2021, 11, 817. [CrossRef] [PubMed]

26. Scott, K. Membrane electrode assemblies for polymer electrolyte membrane fuel cells. In Functional Materials for Sustainable Energy Applications; Elsevier: Amsterdam, The Netherlands, 2012; pp. 279-311.

27. Kim, J.-D.; Ohira, A.; Nakao, H. Chemically Crosslinked Sulfonated Polyphenylsulfone (CSPPSU) Membranes for PEM Fuel Cells. Membranes 2020, 10, 31. [CrossRef] [PubMed]

28. Lin, Y.; Yen, C.-Y.; Ma, C.-C.M.; Liao, S.-H.; Lee, C.-H.; Hsiao, Y.-H.; Lin, H.-P. High proton-conducting Nafion ${ }^{\circledR} /-\mathrm{SO}_{3} \mathrm{H}_{\text {functionalized }}$ mesoporous silica composite membranes. J. Power Sources 2007, 171, 388-395. [CrossRef]

29. Majlan, E.H.; Rohendi, D.; Daud, W.R.W.; Husaini, T.; Haque, M.A. Electrode for proton exchange membrane fuel cells: A review. Renew. Sustain. Energy Rev. 2018, 89, 117-134. [CrossRef]

30. Qiu, B.; Lin, B.; Yan, F. Ionic liquid/poly(ionic liquid)-based electrolytes for energy devices. Polym. Int. 2013, 62, 335-337. [CrossRef]

31. Park, M.J.; Choi, I.; Hong, J.; Kim, O. Polymer electrolytes integrated with ionic liquids for future electroChemical devices. J. Appl. Polym. Sci. 2013, 129, 2363-2376. [CrossRef]

32. Alashkar, A.; Ibrahim, T.; Khamis, M.; Alami, A.H. Electrolytes, Dyes, and Perovskite Materials in Third Generation Photovoltaic Cells. Ref. Modul. Mater. Sci. Mater. Eng. 2021, 2, 621-634. [CrossRef]

33. Hagiwara, R.; Lee, J.S. Ionic Liquids for ElectrChemical Devices. Electrchemistry 2007, 75, 23-34. [CrossRef]

34. Galiński, M.; Lewandowski, A.; Stepniak, I. Ionic liquids as electrolytes. Electrochim. Acta 2006, 51, 5567-5580. [CrossRef]

35. Bara, J.E.; Gin, D.L.; Noble, R.D. Effect of Anion on Gas Separation Performance of Polymer-Room-Temperature Ionic Liquid Composite Membranes. Ind. Eng. Chem. Res. 2008, 47, 9919-9924. [CrossRef]

36. Põhako-Esko, K.; Timusk, M.; Saal, K.; Lõhmus, R.; Kink, I.; Mäeorg, U. Increased conductivity of polymerized ionic liquids through the use of a nonpolymerizable ionic liquid additive. J. Mater. Res. 2013, 28, 3086-3093. [CrossRef]

37. GSaiz, P.; Lopes, A.C.; Eizagirre Barker, S.; Fernández de Luis, R.; Arriortua, M.I. Ionic liquids for the control of the morphology in poly(vinylidene fluoride-co-hexafluoropropylene) membranes. Mater. Des. 2018, 155, 325-333. [CrossRef]

38. Goh, J.T.E.; Abdul Rahim, A.R.; Masdar, M.S.; Shyuan, L.K. Enhanced Performance of Polymer Electrolyte Membranes via Modification with Ionic Liquids for Fuel Cell Applications. Membranes 2021, 11, 395. [CrossRef] 
39. Che, Q.; Fan, H.; Duan, X.; Feng, F.; Mao, W.; Han, X. Layer by layer self-assembly fabrication of high temperature proton exchange membrane based on ionic liquids and polymers. J. Mol. Liq. 2018, 269, 666-674. [CrossRef]

40. Ka'ki, A.; Alraeesi, A.; Al-Othman, A.; Tawalbeh, M. Proton conduction of novel calcium phosphate nanoComposite membranes for high temperature PEM fuel cells applications. Int. J. Hydrog. Energy 2021, 46, 30641-30657. [CrossRef]

41. Miran, M.S.; Yasuda, T.; Susan, M.A.B.H.; Dokko, K.; Watanabe, M. ElectroChemical properties of protic ionic liquids: Correlation between open circuit potential for $\mathrm{H}_{2} / \mathrm{O}_{2}$ cells under non-humidified conditions and $\triangle \mathrm{pKa}$. RSC Adv. 2013, 3, 4141. [CrossRef]

42. Nakamoto, H.; Noda, A.; Hayamizu, K.; Hayashi, S.; Hamaguchi, H.; Watanabe, M. Proton-Conducting Properties of a Brønsted Acid-Base Ionic Liquid and Ionic Melts Consisting of Bis(trifluoromethanesulfonyl)imide and Benzimidazole for Fuel Cell Electrolytes. J. Phys. Chem. C 2007, 111, 1541-1548. [CrossRef]

43. Noda, A.; Susan, M.A.B.H.; Kudo, K.; Mitsushima, S.; Hayamizu, K.; Watanabe, M. Brønsted Acid-Base Ionic Liquids as Proton-Conducting Nonaqueous Electrolytes. J. Phys. Chem. B 2003, 107, 4024-4033. [CrossRef]

44. Wippermann, K.; Wackerl, J.; Lehnert, W.; Huber, B.; Korte, C. 2-Sulfoethylammonium Trifluoromethanesulfonate as an Ionic Liquid for High Temperature PEM Fuel Cells. J. Electrochem. Soc. 2016, 163, F25-F37. [CrossRef]

45. Thomson, J.; Dunn, P.; Holmes, L.; Belieres, J.-P.; Angell, C.A.; Gervasio, D. A Flourinated Ionic Liquid as a High-Performance Fuel Cell Electrolyte. ECS Trans. 2019, 13, 21-29. [CrossRef]

46. Nakamoto, H.; Watanabe, M. Brønsted acid-base ionic liquids for fuel cell electrolytes. Chem. Commun. 2007, $24,2539-2541$. [CrossRef] [PubMed]

47. Miran, M.S.; Yasuda, T.; Susan, M.A.B.H.; Dokko, K.; Watanabe, M. Binary Protic Ionic Liquid Mixtures as a Proton Conductor: High Fuel Cell Reaction Activity and Facile Proton Transport. J. Phys. Chem. C 2014, 118, 27631-27639. [CrossRef]

48. Tang, B.; Gondosiswanto, R.; Hibbert, D.B.; Zhao, C. Critical assessment of superbase-derived protic ionic liquids as electrolytes for electroChemical applications. Electrochim. Acta 2019, 298, 413-420. [CrossRef]

49. Yoshizawa-Fujita, M.; Byrne, N.; Forsyth, M.; MacFarlane, D.R.; Ohno, H. Proton transport properties in zwitterion blends with Brønsted acids. J. Phys. Chem. B 2010, 114, 16373-16380. [CrossRef]

50. Luo, J.; Hu, J.; Saak, W.; Beckhaus, R.; Wittstock, G.; Vankelecom, I.F.J.; Agert, C.; Conrad, O. Protic ionic liquid and ionic melts prepared from methanesulfonic acid and 1H-1,2,4-triazole as high temperature PEMFC electrolytes. J. Mater. Chem. 2011, 21, 10426-10436. [CrossRef]

51. Yoshizawa, M.; Ogihara, W.; Ohno, H. Design of new ionic liquids by neutralization of imidazole derivatives with imide-type acids. Electrochem. Solid-State Lett. 2001, 4, 60-62. [CrossRef]

52. Fernicola, A.; Panero, S.; Scrosati, B.; Tamada, M.; Ohno, H. New Types of Brönsted Acid-Base Ionic Liquids-Based Membranes for Applications in PEMFCs. ChemPhysChem 2007, 8, 1103-1107. [CrossRef]

53. Xiang, J.; Chen, R.; Wu, F.; Li, L.; Chen, S.; Zou, Q. PhysicoChemical properties of new amide-based protic ionic liquids and their use as materials for anhydrous proton conductors. Electrochim. Acta 2011, 56, 7503-7509. [CrossRef]

54. Che, Q.; Sun, B.; He, R. Preparation and characterization of new anhydrous, conducting membranes based on composites of ionic liquid trifluoroacetic propylamine and polymers of sulfonated poly (ether ether) ketone or polyvinylidenefluoride. Electrochim. Acta 2008, 53, 4428-4434. [CrossRef]

55. Langevin, D.; Nguyen, Q.T.; Marais, S.; Karademir, S.; Sanchez, J.-Y.; Iojoiu, C.; Martinez, M.; Mercier, R.; Judeinstein, P.; Chappey, C. High-Temperature Ionic-Conducting Material: Advanced Structure and Improved Performance. J. Phys. Chem. C 2013, 117, 15552-15561. [CrossRef]

56. Luo, J.; Conrad, O.; Vankelecom, I.F.J. PhysicoChemical properties of phosphonium-based and ammonium-based protic ionic liquids. J. Mater. Chem. 2012, 22, 20574-20579. [CrossRef]

57. Lalia, B.S.; Sekhon, S.S. Polymer electrolytes containing ionic liquids with acidic counteranion $\left(\mathrm{DMRImH}_{2} \mathrm{PO}_{4}, \mathrm{R}=\mathrm{ethyl}\right.$, butyl and oCtyl). Chem. Phys. Lett. 2006, 425, 294-300. [CrossRef]

58. Rogalsky, S.; Bardeau, J.-F.; Makhno, S.; Babkina, N.; Tarasyuk, O.; Cherniavska, T.; Orlovska, I.; Kozyrovska, N.; Brovko, O. New proton conducting membrane based on bacterial cellulose/polyaniline nanocomposite film impregnated with guanidinium-based ionic liquid. Polymer 2018, 142, 183-195. [CrossRef]

59. Gao, J.; Liu, J.; Liu, W.; Li, B.; Xin, Y.; Yin, Y.; Jungu; Zho, Z. Proton exchange membrane fuel cell working at elevated temperature with ionic liquid as electrolyte. Int. J. Electrochem. Sci. 2011, 6, 6115-6122.

60. Brigouleix, C.; Anouti, M.; Jacquemin, J.; Caillon-Caravanier, M.; Galiano, H.; Lemordant, D. PhysicoChemical characterization of morpholinium cation based protic ionic liquids used as electrolytes. J. Phys. Chem. B 2010, 114, 1757-1766. [CrossRef]

61. Anouti, M.; Caillon-Caravanier, M.; Dridi, Y.; Galiano, H.; Lemordant, D. Synthesis and characterization of new pyrrolidinium based protic ionic liquids. Good and superionic liquids. J. Phys. Chem. B 2008, 112, 13335-13343. [CrossRef]

62. Susan, M.A.B.H.; Noda, A.; Mitsushima, S.; Watanabe, M. Brønsted acid-base ionic liquids and their use as new materials for anhydrous proton conductors. Chem. Commun. 2003, 8, 938-939. [CrossRef]

63. Lakshminarayana, G.; Nogami, M. Inorganic-organic hybrid membranes with anhydrous proton conduction prepared from tetramethoxysilane/methyl-trimethoxysilane/trimethylphosphate and 1-ethyl-3-methylimidazolium-bis (trifluoromethanesulfonyl) imide for $\mathrm{H}_{2} / \mathrm{O}_{2}$ fuel cells. Electrochim. Acta 2010, 55, 1160-1168. [CrossRef]

64. Li, Z.; Liu, H.; Liu, Y.; He, P.; Li, J. A Room-Temperature Ionic-Liquid-Templated Proton-Conducting Gelatinous Electrolyte. J. Phys. Chem. B 2004, 108, 17512-17518. [CrossRef] 
65. Li, H.; Jiang, F.; Di, Z.; Gu, J. Anhydrous proton-conducting glass membranes doped with ionic liquid for intermediatetemperature fuel cells. Electrochim. Acta 2012, 59, 86-90. [CrossRef]

66. Takahashi, C.; Shirai, T.; Hayashi, Y.; Fuji, M. Study of intercalation compounds using ionic liquids into montmorillonite and their thermal stability. Solid State Ion. 2013, 241, 53-61. [CrossRef]

67. Yasuda, T.; Nakamura, S.; Honda, Y.; Kinugawa, K.; Lee, S.-Y.; Watanabe, M. Effects of Polymer Structure on Properties of Sulfonated Polyimide/Protic Ionic Liquid Composite Membranes for Nonhumidified Fuel Cell Applications. ACS Appl. Mater. Interfaces 2012, 4, 1783-1790. [CrossRef]

68. Ueki, T.; Watanabe, M. Macromolecules in Ionic Liquids: Progress, Challenges, and Opportunities. Macromolecules 2008, 41, 3739-3749. [CrossRef]

69. Díaz, M.; Ortiz, A.; Vilas, M.; Tojo, E.; Ortiz, I. Performance of PEMFC with new polyvinyl-ionic liquids based membranes as electrolytes. Int. J. Hydrog. Energy 2014, 39, 3970-3977. [CrossRef]

70. De Yuso, M.d.V.M.; Cuberes, M.T.; Romero, V.; Neves, L.; Coelhoso, I.; Crespo, J.G.; Rodríguez-Castellón, E.; Benavente, J Modification of a Nafion membrane by n-dodecyltrimethylammonium cation inclusion for potential application in DMFC. Int. J. Hydrog. Energy 2014, 39, 4023-4029. [CrossRef]

71. Di Noto, V.; Piga, M.; Giffin, G.A.; Lavina, S.; Smotkin, E.S.; Sanchez, J.-Y.; Iojoiu, C. Influence of Anions on Proton-Conducting Membranes Based on Neutralized Nafion 117, Triethylammonium Methanesulfonate, and Triethylammonium Perfluorobutanesulfonate. 1. Synthesis and Properties. J. Phys. Chem. C 2012, 116, 1361-1369. [CrossRef]

72. Sun, J.; Jordan, L.R.; Forsyth, M.; MacFarlane, D.R. Acid-Organic base swollen polymer membranes. Electrochim. Acta 2001, 46, 1703-1708. [CrossRef]

73. Sood, R.; Iojoiu, C.; Espuche, E.; Gouanvé, F.; Gebel, G.; Mendil-Jakani, H.; Lyonnard, S.; Jestin, J. Proton Conducting Ionic Liquid Doped Nafion Membranes: Nano-Structuration, Transport Properties and Water Sorption. J. Phys. Chem. C 2012, 116, 24413-24423. [CrossRef]

74. Schauer, J.; Sikora, A.; Plíšková, M.; Mališ, J.; Mazúr, P.; Paidar, M.; Bouzek, K. Ion-conductive polymer membranes containing 1-butyl-3-methylimidazolium trifluoromethanesulfonate and 1-ethylimidazolium trifluoromethanesulfonate. J. Membr. Sci. 2011, 367, 332-339. [CrossRef]

75. Iojoiu, C.; Martinez, M.; Hanna, M.; Molmeret, Y.; Cointeaux, L.; Leprêtre, J.-C.; El Kissi, N.; Guindet, J.; Judeinstein, P.; Sanchez, J.-Y. PILs-based Nafion membranes: A route to high-temperature PEFMCs dedicated to electric and hybrid vehicles. Polym. Adv. Technol. 2008, 19, 1406-1414. [CrossRef]

76. Zanchet, L.; da Trindade, L.G.; Bariviera, W.; Borba, K.M.N.; Santos, R.D.M.; Paganin, V.A.; de Oliveira, C.P.; Ticianelli, E.A.; Martini, E.M.A.; de Souza, M.O. 3-Triethylammonium propane sulfonate ionic liquids for Nafion-based composite membranes for PEM fuel cells. J. Mater. Sci. 2020, 55, 6928-6941. [CrossRef]

77. Kumar, M.; Venkatnathan, A. Mechanism of Proton Transport in Ionic-Liquid-Doped Perfluorosulfonic Acid Membranes. J. Phys. Chem. B 2013, 117, 14449-14456. [CrossRef]

78. Lu, F.; Gao, X.; Yan, X.; Gao, H.; Shi, L.; Jia, H.; Zheng, L. Preparation and Characterization of Nonaqueous Proton-Conducting Membranes with Protic Ionic Liquids. ACS Appl. Mater. Interfaces 2013, 5, 7626-7632. [CrossRef]

79. Thayumanasundaram, S.; Piga, M.; Lavina, S.; Negro, E.; Jeyapandian, M.; Ghassemzadeh, L.; Müller, K.; Di Noto, V. Hybrid inorganic-organic proton conducting membranes based on $\mathrm{Nafion}, \mathrm{SiO}_{2}$ and triethylammonium trifluoromethanesulfonate ionic liquid. Electrochim. Acta 2010, 55, 1355-1365. [CrossRef]

80. Li, Y.; Shi, Y.; Mehio, N.; Tan, M.; Wang, Z.; Hu, X.; Chen, G.; Dai, S.; Jin, X. More sustainable electricity generation in hot and dry fuel cells with a novel hybrid membrane of Nafion/nano-silica/hydroxyl ionic liquid. Appl. Energy 2016, 175, 451-458. [CrossRef]

81. Mishra, A.K.; Kuila, T.; Kim, D.-Y.; Kim, N.H.; Lee, J.H. Protic ionic liquid-functionalized mesoporous silica-based hybrid membranes for proton exchange membrane fuel cells. J. Mater. Chem. 2012, 22, 24366-24372. [CrossRef]

82. Maiti, J.; Kakati, N.; Woo, S.P.; Yoon, Y.S. Nafion ${ }^{\circledR}$ based hybrid composite membrane containing GO and dihydrogen phosphate functionalized ionic liquid for high temperature polymer electrolyte membrane fuel cell. Compos. Sci. Technol. 2018, 155, 189-196. [CrossRef]

83. Epping Martin, K.; Kopasz, J.P. The U.S. DOEs High Temperature Membrane Effort. Fuel Cells 2009, 9, 356-362. [CrossRef]

84. Yandrasits, M.A.; Lindell, M.J.; Hamrock, S.J. New directions in perfluoroalkyl sulfonic acid-based proton-exchange membranes Curr. Opin. Electrochem. 2019, 18, 90-98. [CrossRef]

85. Martinelli, A.; Matic, A.; Jacobsson, P.; Börjesson, L.; Fernicola, A.; Panero, S.; Scrosati, B.; Ohno, H. Physical Properties of Proton Conducting Membranes Based on a Protic Ionic Liquid. J. Phys. Chem. B 2007, 111, 12462-12467. [CrossRef] [PubMed]

86. Lee, J.S.; Nohira, T.; Hagiwara, R. Novel composite electrolyte membranes consisting of fluorohydrogenate ionic liquid and polymers for the unhumidified intermediate temperature fuel cell. J. Power Sources 2007, 171, 535-539. [CrossRef]

87. Gao, J.; Guo, Y.; Wu, B.; Qi, L.; Li, B.; Liu, J.; Wang, Z.; Liu, W.; Gu, J.; Zou, Z. Impact of cation selection on proton exchange membrane fuel cell performance with trimethylethyl amide, ethylpyridinium and ethylmethyl imidazolium ionic liquid carried by poly(vinylidene fluoride) membrane as electrolyte. J. Power Sources 2014, 251, 432-438. [CrossRef]

88. Nair, M.G.; Mohapatra, S.R. Perchloric acid functionalized nano-silica and protic ionic liquid based non-aqueous proton conductive polymer electrolytes. Mater. Lett. 2019, 251, 148-151. [CrossRef]

89. Kumar, G.G.; Kim, P.; Nahm, K.S.; Elizabeth, R.N. Structural characterization of PVdF-HFP/PEG/Al2O3 proton conducting membranes for fuel cells. J. Membr. Sci. 2007, 303, 126-131. [CrossRef] 
90. Inan, T.Y.; Doğan, H.; Unveren, E.E.; Eker, E. Sulfonated PEEK and fluorinated polymer based blends for fuel cell applications: Investigation of the effect of type and molecular weight of the fluorinated polymers on the membrane's properties. Int. J. Hydrog. Energy 2010, 35, 12038-12053. [CrossRef]

91. Kumar, G.G.; Kim, P.; Kim, A.R.; Nahm, K.S.; Elizabeth, R.N. Structural, thermal and ion transport studies of different particle size nanoComposite fillers incorporated PVdF-HFP hybrid membranes. Mater. Chem. Phys. 2009, 115, 40-46. [CrossRef]

92. Miao, R.; Liu, B.; Zhu, Z.; Liu, Y.; Li, J.; Wang, X.; Li, Q. PVDF-HFP-based porous polymer electrolyte membranes for lithium-ion batteries. J. Power Sources 2008, 184, 420-426. [CrossRef]

93. Mališ, J.; Mazúr, P.; Schauer, J.; Paidar, M.; Bouzek, K. Polymer-supported 1-butyl-3-methylimidazolium trifluoromethanesulfonate and 1-ethylimidazolium trifluoromethanesulfonate as electrolytes for the high temperature PEM-type fuel cell. Int. J. Hydrog. Energy 2013, 38, 4697-4704. [CrossRef]

94. Escorihuela, J.; Olvera-Mancilla, J.; Alexandrova, L.; Felipe del Castillo, L.; Compañ, V. Recent Progress in the Development of Composite Membranes Based on Polybenzimidazole for High Temperature Proton Exchange Membrane (PEM) Fuel Cell Applications. Polymers 2020, 12, 1861. [CrossRef]

95. Eguizábal, A.; Lemus, J.; Pina, M.P. On the incorporation of protic ionic liquids imbibed in large pore zeolites to polybenzimidazole membranes for high temperature proton exchange membrane fuel cells. J. Power Sources 2013, 222, 483-492. [CrossRef]

96. Van de Ven, E.; Chairuna, A.; Merle, G.; Benito, S.P.; Borneman, Z.; Nijmeijer, K. Ionic liquid doped polybenzimidazole membranes for high temperature Proton Exchange Membrane fuel cell applications. J. Power Sources 2013, 222, 202-209. [CrossRef]

97. Ye, H.; Huang, J.; Xu, J.J.; Kodiweera, N.K.A.C.; Jayakody, J.R.P.; Greenbaum, S.G. New membranes based on ionic liquids for PEM fuel cells at elevated temperatures. J. Power Sources 2008, 178, 651-660. [CrossRef]

98. Liu, S.; Zhou, L.; Wang, P.; Zhang, F.; Yu, S.; Shao, Z.; Yi, B. Ionic-Liquid-Based Proton Conducting Membranes for Anhydrous $\mathrm{H}_{2} / \mathrm{Cl}_{2}$ Fuel-Cell Applications. ACS Appl. Mater. Interfaces 2014, 6, 3195-3200. [CrossRef]

99. Wang, X.; Wang, S.; Liu, C.; Li, J.; Liu, F.; Tian, X.; Chen, H.; Mao, T.; Xu, J.; Wang, Z. Cage-like cross-linked membranes with excellent ionic liquid retention and elevated proton conductivity for HT-PEMFCs. Electrochim. Acta 2018, 283, 691-698. [CrossRef]

100. Eguizábal, A.; Lemus, J.; Roda, V.; Urbiztondo, M.; Barreras, F.; Pina, M.P. Nanostructured electrolyte membranes based on zeotypes, protic ionic liquids and porous PBI membranes: Preparation, characterization and MEA testing. Int. J. Hydrog. Energy 2012, 37, 7221-7234. [CrossRef]

101. Lemus, J.; Eguizábal, A.; Pina, M.P. Endurance strategies for the preparation of high temperature polymer electrolyte membranes by UV polymerization of 1-H-3-vinylimidazolium bis(trifluoromethanesulfonyl)imide for fuel cell applications. Int. J. Hydrog. Energy 2016, 41, 3981-3993. [CrossRef]

102. Kallem, P.; Eguizabal, A.; Mallada, R.; Pina, M.P. Constructing Straight Polyionic Liquid MicroChannels for Fast Anhydrous Proton Transport. ACS Appl. Mater. Interfaces 2016, 8, 35377-35389. [CrossRef]

103. Kallem, P.; Drobek, M.; Julbe, A.; Vriezekolk, E.J.; Mallada, R.; Pina, M.P. Hierarchical Porous Polybenzimidazole Microsieves: An Efficient Architecture for Anhydrous Proton Transport via Polyionic Liquids. ACS Appl. Mater. Interfaces 2017, 9, 14844-14857. [CrossRef]

104. Nawn, G.; Pace, G.; Lavina, S.; Vezzù, K.; Negro, E.; Bertasi, F.; Polizzi, S.; Di Noto, V. NanoComposite Membranes based on Polybenzimidazole and $\mathrm{ZrO}_{2}$ for High-Temperature Proton Exchange Membrane Fuel Cells. ChemSusChem 2015, 8, 1381-1393. [CrossRef]

105. Xu, C.; Liu, X.; Cheng, J.; Scott, K. A polybenzimidazole/ionic-liquid-graphite-oxide composite membrane for high temperature polymer electrolyte membrane fuel cells. J. Power Sources 2015, 274, 922-927. [CrossRef]

106. Hooshyari, K.; Javanbakht, M.; Adibi, M. Novel composite membranes based on PBI and dicationic ionic liquids for high temperature polymer electrolyte membrane fuel cells. Electrochim. Acta 2016, 205, 142-152. [CrossRef]

107. Liu, F.; Wang, S.; Li, J.; Tian, X.; Wang, X.; Chen, H.; Wang, Z. Polybenzimidazole/ionic-liquid-functional silica composite membranes with improved proton conductivity for high temperature proton exchange membrane fuel cells. J. Membr. Sci. 2017, 541, 492-499. [CrossRef]

108. Jothi, P.R.; Dharmalingam, S. An efficient proton conducting electrolyte membrane for high temperature fuel cell in aqueous-free medium. J. Membr. Sci. 2014, 450, 389-396. [CrossRef]

109. Li, Y.; Zhang, M.; Wang, X.; Li, Z.; Zhao, L. Anhydrous conducting composite membranes composed of SPEEK/silica/ionic liquids for high-temperature proton exchange. Electrochim. Acta 2016, 222, 1308-1315. [CrossRef]

110. Arias, J.J.R.; Carlos Dutra, J.; Gomes, A.d.S. Hybrid membranes of sulfonated poly ether ether ketone, ionic liquid and organically modified montmorillonite for proton exchange membranes with enhanced ionic conductivity and ionic liquid lixiviation protection. J. Membr. Sci. 2017, 537, 353-361. [CrossRef]

111. Wang, X.; Jin, M.; Li, Y.; Zhao, L. The influence of various ionic liquids on the properties of SPEEK membrane doped with mesoporous silica. Electrochim. Acta 2017, 257, 290-300. [CrossRef]

112. Batalha, J.A.F.L.; Dahmouche, K.; Sampaio, R.B.; Gomes, A.d.S. Structure and Properties of New sPEEK/Zirconia/Protic Ionic Liquid Membranes for Fuel Cell Application. Macromol. Mater. Eng. 2017, 302, 1600301. [CrossRef]

113. Che, Q.; Zhou, L.; Wang, J. Fabrication and characterization of phosphoric acid doped imidazolium ionic liquid polymer composite membranes. J. Mol. Liq. 2015, 206, 10-18. [CrossRef]

114. da Trindade, L.G.; Zanchet, L.; Souza, J.C.; Leite, E.R.; Martini, E.M.A.; Pereira, E.C. Enhancement of sulfonated poly(ether ether ketone)-based proton exchange membranes doped with different ionic liquids cations. Ionics 2020, 26, 5661-5672. [CrossRef] 
115. Elumalai, V.; Ganesh, T.; Selvakumar, C.; Sangeetha, D. Phosphonate ionic liquid immobilised SBA-15/SPEEK composite membranes for high temperature proton exchange membrane fuel cells. Mater. Sci. Energy Technol. 2018, 1, 196-204. [CrossRef]

116. Chen, B.-K.; Wu, T.-Y.; Kuo, C.-W.; Peng, Y.-C.; Shih, I.-C.; Hao, L.; Sun, I.-W. 4,4'-Oxydianiline (ODA) containing sulfonated polyimide/protic ionic liquid composite membranes for anhydrous proton conduction. Int. J. Hydrog. Energy 2013, 38, 11321-11330. [CrossRef]

117. Deligöz, H.; Yılmazoğlu, M. Development of a new highly conductive and thermomechanically stable complex membrane based on sulfonated polyimide/ionic liquid for high temperature anhydrous fuel cells. J. Power Sources 2011, 196, 3496-3502. [CrossRef]

118. Lee, S.-Y.; Yasuda, T.; Watanabe, M. Fabrication of protic ionic liquid/sulfonated polyimide composite membranes for nonhumidified fuel cells. J. Power Sources 2010, 195, 5909-5914. [CrossRef]

119. Chen, B.-K.; Wong, J.-M.; Wu, T.-Y.; Chen, L.-C.; Shih, I.-C. Improving the Conductivity of Sulfonated Polyimides as Proton Exchange Membranes by Doping of a Protic Ionic Liquid. Polymers 2014, 6, 2720-2736. [CrossRef]

120. Kowsari, E.; Zare, A.; Ansari, V. Phosphoric acid-doped ionic liquid-functionalized graphene oxide/sulfonated polyimide composites as proton exchange membrane. Int. J. Hydrog. Energy 2015, 40, 13964-13978. [CrossRef]

121. Zhang, X.; Fu, X.; Yang, S.; Zhang, Y.; Zhang, R.; Hu, S.; Bao, X.; Zhao, F.; Li, X.; Liu, Q. Design of sepiolite-supported ionogelembedded composite membranes without proton carrier wastage for wide-temperature-range operation of proton exchange membrane fuel cells. J. Mater. Chem. A 2019, 7, 15288-15301. [CrossRef]

122. Li, J.; Wang, S.; Xu, J.; Xu, L.; Liu, F.; Tian, X.; Wang, Z. Organic-inorganic composite membrane based on sulfonated poly (arylene ether ketone sulfone) with excellent long-term stability for proton exchange membrane fuel cells. J. Membr. Sci. 2017, 529, 243-251. [CrossRef]

123. Awasthi, S.; Gaur, B. Polymer Electrolytes: Ionic Liquid Modified Phenolphthalein Based Hybrid Multiblock Poly (Arylene Ether) Copolymers. J. Electrochem. Soc. 2017, 164, H5057. [CrossRef]

124. Dahi, A.; Fatyeyeva, K.; Langevin, D.; Chappey, C.; Rogalsky, S.P.; Tarasyuk, O.; Marais, S. Polyimide/ionic liquid composite membranes for fuel cells operating at high temperatures. Electrochim. Acta 2014, 130, 830-840. [CrossRef]

125. Zakeri, M.; Abouzari-Lotf, E.; Nasef, M.M.; Ahmad, A.; Miyake, M.; Ting, T.M.; Sithambaranathan, P.; Ming, T.T. Fabrication and characterization of supported dual acidic ionic liquids for polymer electrolyte membrane fuel cell applications. Arab. J. Chem. 2019, 12, 1011-1023. [CrossRef]

126. Zakeri, M.; Abouzari-Lotf, E.; Nasef, M.M.; Ahmad, A.; Ripin, A.; Ting, T.M.; Sithambaranathan, P. Preparation and characterization of highly stable protic-ionic-liquid membranes. Int. J. Hydrog. Energy 2019, 44, 30732-30742. [CrossRef]

127. Tang, Q.; Li, Y.; Tang, Z.; Wu, J.; Lin, J.; Huang, M. Anhydrous proton exchange membrane operated at $200{ }^{\circ} \mathrm{C}$ and a well-aligned anode catalyst. J. Mater. Chem. 2011, 21, 16010-16017. [CrossRef]

128. Tang, Q.; Wu, J.; Tang, Z.; Li, Y.; Lin, J. High-temperature proton exchange membranes from ionic liquid absorbed/doped superabsorbents. J. Mater. Chem. 2012, 22, 15836-15844. [CrossRef]

129. Chopade, S.A.; So, S.; Hillmyer, M.A.; Lodge, T.P. Anhydrous Proton Conducting Polymer Electrolyte Membranes via Polymerization-Induced Microphase Separation. ACS Appl. Mater. Interfaces 2016, 8, 6200-6210. [CrossRef]

130. Chu, F.; Lin, B.; Yan, F.; Qiu, L.; Lu, J. Macromolecular protic ionic liquid-based proton-conducting membranes for anhydrous proton exchange membrane application. J. Power Sources 2011, 196, 7979-7984. [CrossRef]

131. Lin, B.; Yuan, W.; Xu, F.; Chen, Q.; Zhu, H.; Li, X.; Yuan, N.; Chu, F.; Ding, J. Protic ionic liquid/functionalized graphene oxide hybrid membranes for high temperature proton exchange membrane fuel cell applications. Appl. Surf. Sci. 2018, 455, $295-301$. [CrossRef]

132. Thanganathan, U.; Nogami, M. Investigations on effects of the incorporation of various ionic liquids on PVA based hybrid membranes for proton exchange membrane fuel cells. Int. J. Hydrog. Energy 2015, 40, 1935-1944. [CrossRef]

133. Yang, Y.; Gao, H.; Zheng, L. Anhydrous proton exchange membranes at elevated temperatures: Effect of protic ionic liquids and crosslinker on proton conductivity. RSC Adv. 2015, 5, 17683-17689. [CrossRef]

134. Wu, W.; Zou, G.; Fang, X.; Cong, C.; Zhou, Q. Effect of Methylimidazole Groups on the Performance of Poly(phenylene oxide) Based Membrane for High-Temperature Proton Exchange Membrane Fuel Cells. Ind. Eng. Chem. Res. 2017, 56, 10227-10234. [CrossRef]

135. Al-Othman, A.; Tremblay, A.Y.; Pell, W.; Letaief, S.; Burchell, T.J.; Peppley, B.A.; Ternan, M. Zirconium phosphate as the proton conducting material in direct hydrocarbon polymer electrolyte membrane fuel cells operating above the boiling point of water. $J$. Power Sources 2010, 195, 2520-2525. [CrossRef]

136. Al-Othman, A.; Tremblay, A.Y.; Pell, W.; Letaief, S.; Liu, Y.; Peppley, B.A.; Ternan, M. A modified silicic acid (Si) and sulphuric acid (S)-ZrP/PTFE/glycerol composite membrane for high temperature direct hydrocarbon fuel cells. J. Power Sources 2013, 224, 158-167. [CrossRef]

137. Al-Othman, A.; Tremblay, A.Y.; Pell, W.; Liu, Y.; Peppley, B.A.; Ternan, M. The effect of glycerol on the conductivity of Nafion-free $\mathrm{ZrP} /$ PTFE composite membrane electrolytes for direct hydrocarbon fuel cells. J. Power Sources 2012, 199, 14-21. [CrossRef]

138. Al-Othman, A.; Zhu, Y.; Tawalbeh, M.; Tremblay, A.Y.; Ternan, M. Proton conductivity and morphology of new composite membranes based on zirconium phosphates, phosphotungstic acid, and silicic acid for direct hydrocarbon fuel cells applications. J. Porous Mater. 2017, 24, 721-729. [CrossRef]

139. Mohammed, H.; Al-Othman, A.; Nancarrow, P.; Elsayed, Y.; Tawalbeh, M. Enhanced proton conduction in zirconium phosphate/ionic liquids materials for high-temperature fuel cells. Int. J. Hydrog. Energy 2021, 46, 4857-4869. [CrossRef] 
140. Al-Othman, A.; Nancarrow, P.; Tawalbeh, M.; Ka'Ki, A.; El-Ahwal, K.; El Taher, B.; Alkasrawi, M. Novel composite membrane based on zirconium phosphate-ionic liquids for high temperature PEM fuel cells. Int. J. Hydrog. Energy 2021, 46, 6100-6109. [CrossRef]

141. Ortiz-Martínez, V.M.; Ortiz, A.; Fernández-Stefanuto, V.; Tojo, E.; Colpaert, M.; Améduri, B.; Ortiz, I. Fuel cell electrolyte membranes based on copolymers of protic ionic liquid [HSO3-BVIm][TfO] with MMA and hPFSVE. Polymer Guildf. 2019, 179, 121583. [CrossRef]

142. Zhu, H.; Li, R.; Wang, F.; Chen, N.; Li, Z.; Wang, Z. Poly tris (1-imidazolyl) benzene ionic liquids/Poly (2,6-dimethyl phenylene oxide) composite membranes for anion exchange membrane fuel cells. J. Mater. Sci. 2017, 52, 11109-11119. [CrossRef]

143. Eisa, A.; Al-Othman, A.; Al-Sayah, M.; Tawalbeh, M. Novel Composite Membranes Based on Polyaniline/Ionic Liquids for PEM Fuel Cells Applications. Key Eng. Mater. 2020, 865, 55-60. [CrossRef]

144. Fu, R.-Q.; Julius, D.; Hong, L.; Lee, J.-Y. PPO-based acid-base polymer blend membranes for direct methanol fuel cells. J. Membr. Sci. 2008, 322, 331-338. [CrossRef]

145. Yang, S.; Gong, C.; Guan, R.; Zou, H.; Dai, H. Sulfonated poly(phenylene oxide) membranes as promising materials for new proton exchange membranes. Polym. Adv. Technol. 2006, 17, 360-365. [CrossRef]

146. Liu, S.; Wu, D.; Akcora, P. Ion-Containing Polymer-Grafted Nanoparticles in Ionic Liquids: Implications for Polymer Electrolyte Membranes. ACS Appl. Nano Mater. 2021, 4, 8108-8115. [CrossRef]

147. Zhang, Z.; Ren, J.; Xu, J.; Meng, L.; Zhao, P.; Wang, H.; Wang, Z. Enhanced proton conductivity of sulfonated poly(arylene ether ketone sulfone) polymers by incorporating phosphotungstic acid-ionic-liquid-functionalized metal-organic framework. J. Membr. Sci. 2021, 630, 119304. [CrossRef]

148. Wang, Z.; Li, X.; Zhao, C.; Ni, H.; Na, H. Synthesis and characterization of sulfonated poly(arylene ether ketone ketone sulfone) membranes for application in proton exchange membrane fuel cells. J. Power Sources 2006, 160, 969-976. [CrossRef]

149. Okonkwo, P.C.; Ikram Ben Belgacem, I.B.; Emoric, W.; Uzomad, P.C. Nafion degradation mechanisms in proton exchange membrane fuel cell (PEMFC) system: A review. Int. J. Hydrog. Energy 2021, 46, 27956-27973. [CrossRef]

150. Zhao, J.; Li, X. A review of polymer electrolyte membrane fuel cell durability for vehicular applications: Degradation modes and experimental techniques. Energy Convers. Manag. 2019, 199, 112022. [CrossRef]

151. Wu, J.; Yuan, X.Z.; Martin, J.J.; Wang, H.; Zhang, J.; Shen, J.; Wu, S.; Merida, W. A review of PEM fuel cell durability: Degradation mechanisms and mitigation strategies. J. Power Sources 2008, 184, 104-119. [CrossRef]

152. Moreno, M.; Ali Aboudzadeh, M.; Barandiaran, M.J.; Mecerreyes, D. Facile incorporation of natural carboxylic acids into polymers via polymerization of protic ionic liquids. J. Polym. Sci. Part A Polym. Chem. 2012, 50, 1049-1053. [CrossRef] 